\title{
MARKING OF QUALITY MODIFIERS IN 2ND-GENERATION IE LANGUAGES
}

\author{
ARTEMIJ KEIDAN \\ Sapienza University of Rome \\ artemij.keidan@uniroma1.it
}

\begin{abstract}
In PIE, quality modifiers were expressed by stative verbs and nominal epithets, rather than by special adjectival lexemes. Adjectives did not form a separate lexical class. This made the encoding of the NP constituency less explicit. If we consider what I suggest calling "second-generation IE languages" we can observe a general tendency to create new, more explicit morphological means of dependency marking within a NP. The exact outcomes of this diachronic process vary from one language to another. However, if we parametrise the variation, a common pattern becomes clearly observable. In all the languages analysed in the present paper, there is a pronoun undergoing grammaticalisation as a dependency marker. What varies is (1) the position of this element with respect to the nominal base (pre- vs. postposed); (2) the degree of agglutination (bound morpheme vs. clitic vs. free morpheme); and (3) the locus of marking (head vs. modifier vs. double or alternant marking); (4) the source morpheme that undergoes grammaticalisation (relative vs. demonstrative pronoun).
\end{abstract}

KEYWORDS: Indo-European; adjective; quality modifiers; dependency marking.

\section{Proposed hypothesis}

In the present study I am dealing with a grammaticalisation pattern shared by a number of IE languages, which, to my knowledge, has never been considered in its entirety as a typological isogloss. The languages involved in this innovation are not close relatives; rather, they occupy one and the same chronological slot, or "generation", as it will be called in $\$ 1.2$, within the Indo-European domain. A certain degree of formal variability is observed language-specifically, and an attempt to disentangle it through a parametric approach to the data is consequently suggested. 


\subsection{A necessary assumption: the lack of adjectives in PIE}

The grammatical domain to which this innovation refers is the coding of the quality modifiers of nominal heads. In the Standard Average European type convincingly described as a Sprachbund by Haspelmath (2001) - this syntactic function is usually fulfilled by a specific lexical class; namely, the adjective. However, this was not necessarily the case in the past, especially not in PIE. The following features can be assumed as prototypical for defining adjectives:

(a) quality-denoting semantics;

(b) special syntactic behaviour (e.g. rigid position with respect to the head noun);

(c) special morphological behaviour (agreement with the head noun by gender, number, case, or the like);

(d) special morphological markers (i.e. special adjectival affixes);

(e) special paradigm structure (e.g. the inclusion of multiple genders and gradation in the adjectival paradigm).

If a language has a well-defined class of lexemes that can be considered "born modifiers" (cf. Lehmann 2018: §3.2.4), and that comply with most of the formal properties of the list above, then such lexemes can be considered adjectives. If no lexical class can be so defined, then there are no adjectives in the language. The latter situation is observed in Vedic Sanskrit, as shown by Alfieri (2016): only around a dozen of the so-called "primary adjectives", i.e. non-derived adjectival lexemes, are attested here (and even those are probably derived; we are merely unable to reconstruct the roots from which they derive). The slot of the quality modifier of a noun head can be occupied by different constructions, such as: stative intransitive verbs, verbal nominalisations (participles), nominal epithets, and others. The situation in Vedic can be considered a good approximation of the state of affairs in PIE.

Note that some nominal epithets could agree with their head nouns in number and gender; however, this did not make them adjectives, because this feature was not exclusive to the members of just one lexical class. Let us borrow two examples from Lehmann (2018: 56). ${ }^{1}$ The Latin NP in (1a) can have two interpretations, depending on which word is considered the head, and which the modifier, since each of them can be considered to agree with the other. In

\footnotetext{
${ }^{1}$ Here and below the glossing of linguistic examples is limited to the relevant information, i.e. to nominal categories, and sometimes only to the case.
} 
(1b) we see a verse from Plautus where a typical noun, asinus 'ass', is effectively used as a modifier and therefore agrees with the head noun homines 'men'; moreover, it exhibits gradation, another typically adjectival feature.
inimici
Germani
enemy-M.NOM.PL German-M.NOM.PL
'German enemies'/'hostile Germans'

(1b)

$\begin{array}{lll}\text { homines } & \text { magis asinos } & \text { numquam vidi } \\ \text { man-M.ACC.PL more ass-M.ACC.PL } & \text { never seen }\end{array}$

'I have never seen human beings who were such asses.' (Pl. Pseud. 136).

Adjectives are logically excluded also in the case of a consistent head-marking strategy: since the modifier does not undergo any morphological change, there is no restriction on the kind of words that can occupy this slot. Thus, in New Persian any nominal can occur either as a head or as a modifier within a NP (see the ezāfe constructions in (9)).

What we observe in the whole picture is, therefore, a prolonged drift from the PIE system, with no adjectival class and a highly variable coding of the quality modifiers, to the modern IE systems where quality modifiers have a standard coding, which represents a significant simplification of the grammatical procedures (cf. Lehmann 2018: §6). As I will attempt to show, in a group of IE languages a common pattern was employed for developing one such standard coding. It was not inherited from PIE but nonetheless spread gradually among various daughter languages, frequently crossing the boundaries of the IE branches. The present study is devoted to the analysis of this drift.

\subsection{Generations of IE languages}

I propose to enrich the classical terminology of Indo-European linguistics, much of which is based on the kinship metaphor, with a new term: the generation. The three supposed generations are defined on purely typological grounds. Two languages belong to the same generation if they share some typical features of this generation, regardless of the date of attestation. The only connection with chronology is that generations are ordered: a language enters the 3 rd generation only after the 2 nd, and the latter only after the 1 st. However, 
each language evolves through generations independently from the others, and can also pause at one stage without passing to the next.

Thus, the generation becomes a measure of the degree of conservativeness of a language within the IE family. For example, if a contemporary IE language presents a good number of typical 1st or 2nd generation characteristics, it can be considered a conservative variety. Contrariwise, if an ancient IE language presents features that are typical of the 2 nd or the 3 rd generation, then it is clearly an innovating one.

The following is just a provisional list of languages distributed per generations, made for illustrative purposes only. Based as it is on an intuitive estimation of the degree of conservativeness vs. innovativeness of single IE languages, it can be reconsidered in the future studies.

- The 0th generation is Proto-Indo-European (be it a real language on its own, or just a set of regular correspondences).

- The 1st generation corresponds to the oldest attested IE languages, such as Vedic Sanskrit, Gathic Avestan, Mycenaean, Homeric Greek and, to a lesser degree, Latin.

- The 2nd generation ranges from the youngest attestations of the "old" IE languages (e.g. Epic and Buddhist Sanskrit, Young Avestan, Late Old Persian), to such languages as Pāli and Prakrits (for the Indo-Aryan branch), varieties of Middle West and East Iranian, Classical to Koiné Greek, Classical to Vulgar Latin; in the same group can be also included such IE branches as Balto-Slavic, Germanic and Tocharian which lack any attestation of the 1st generation stage.

- The 3rd generation corresponds to most of the modern IE languages, from their earliest attestations to the present days: modern Germanic, Slavic and Romance languages, Modern Indian and Iranian varieties, Modern Greek, etc. Some of the IE languages, such as Albanian, are only known from this stage.

The generational labels are convenient cover words referring to the stages of the typological evolution of the IE languages. For example, Belardi's (1990; 1993) distinction between the "internally articulated" IE varieties (presenting non-fused morphemes, internal inflection, transparent morphonology, and pitch accent) and the "internally opaque" ones (with a high degree of fusion, opaque stems, typically stress accent) can be reformulated in terms of a passage from the 1 st to the 2 nd generation. Also, the evolution from analyticity to synthesis, 
alongside the fixation of the word order and the increase of transitivity, described in Bauer (1995), can be given a similar generational interpretation. ${ }^{2}$

A detailed survey of the structural properties of each generation is a matter of ongoing research (but see a brief summary in Keidan 2013). In the present study I will describe the reinforcement of the quality modifiers' marking as a 2nd generation feature. The feature appears in many of the non-archaic IE languages, but does not come from any specific PIE source. Under analysis here is the origin and development of this feature in each of the IE branches in which it is attested.

\subsection{Grammaticalisation of the pronominal element as a quality modifier marker}

Among the 2nd generation IE languages a common tendency can be observed: a redundant pronominal element was inserted in various positions within the $\mathrm{NP}$ in order to reinforce the marking of the quality modifiers. This grammaticalisation process is represented by the two diagrams in Figure 1.

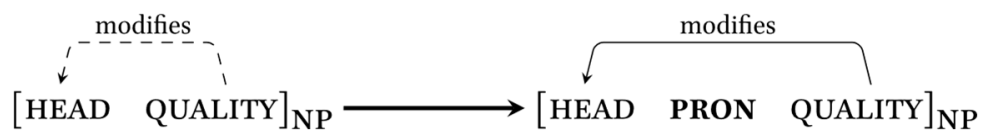

Figure 1. Grammaticalisation of PRON.

The diagram on the left depicts the state of affairs attested in the 1st generation languages and, accordingly, reconstructed for PIE: the dependency between modifier and head is not marked with a standard marker (hence the dashed line arrow). The diagram on the right represents the new pattern which emerged after the grammaticalisation of the pronominal element in the 2nd generation IE languages: the dependency now has an explicit and specialised marker (hence the solid line arrow). The inserted pronominal element is henceforth glossed as PRON.

\footnotetext{
${ }^{2}$ Another possible feature characterising the change from the 1 st to the 2 nd generation, suggested by one of the anonymous reviewers, is the passive verb form, which is found in (virtually) all 2nd generation languages but, given the differences in the markers and the scarcity of attestations in the 1st generation languages, it is hard to know what - if anything - to reconstruct for PIE.
} 
It seems natural to present this development as the result of the grammaticalisation of a relative clause, going through the stage of a verbless adnominal relative construction. The grammaticalisation process must have gone through the following steps:

(a) deletion of the predicate (copula);

(b) deletion of the "correlative" demonstrative pronoun opposed to the relative (of the type "that... which");

(c) agreement of PRON with the antecedent to which it refers, i.e. the head noun which it qualifies;

(d) diffusion of the new construction from the nominative case only to the other cases;

(e) fixation of the mutual order of head, PRON and modifier;

(f) gradual loss of syntactic autonomy of PRON with respect to the head noun (more on this in §1.4.2);

(g) PRON becomes the main nominal modifier marker.

A similar explanation is provided by Haider and Zwanziger (1984: §2) for such constructions in Avestan and Middle Persian. However, it is only in the Iranian domain that we can clearly observe all the chronological steps of this grammaticalisation process. In most of the other 2 nd generation languages the innovation is observed only in its final stage, with few or no traces of the preceding relative clause.

\subsection{Parametric approach}

The innovation described above is attested in a vast geographic area, but took individual paths in each language within the isogloss. Consequently, the starting pattern was distorted to the degree that we often cannot easily recognise it in the later stages of each language. A one-dimensional scale of grammaticalisation, such as that presented in $\S 1.3$, is impractical when describing such a varied set of diachronic developments. A multidimensional set of parameters seems a better solution. If we try, so to say, to "rewind" such parametrical distortions back in time, the initial pattern will clearly come out again. The parameters taken into consideration here are briefly surveyed in the following sections. 


\subsubsection{Locus of marking}

It is largely accepted, since Nichols' seminal paper (1986), that the way languages mark the dependency between words, for instance, between a nominal head and its quality modifiers, can be used as a parameter for typological classification. The following types are usually individuated:

(a) dependent-marking, as with adjectives that exhibit special endings and/or agreement with the nominal head;

(b) head-marking, when a special mark pre-signals that a given head has a modifier after it (cf. the ezāfe construction in Persian, §2.2.1);

(c) double marking: this is a redundant marking of both the head and the modifier word with some special morphological mark, such as an article, in order to denote the fact that they both belong to the same phrase (cf. the redundant article in Greek, §2.3.3).

After the grammaticalisation of PRON, the resulting construction aligned to one of these three types. This is the main reason why the resulting constructions are so dissimilar from each other. Figure 2 represents two such types, or strategies: head-marking and dependent-marking; note that the linear order of PRON with respect to the word it cliticises to is only conventional on this scheme, since the effective position of the mark can vary from preposed to postposed (see $\S 1.4 .3$ ).
modifies

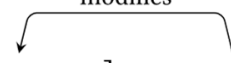

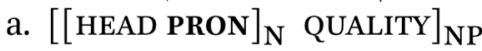

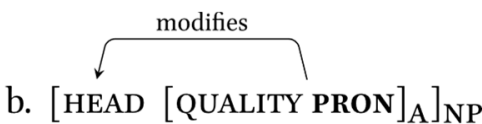

Figure 2. Two strategies: (a) head-marking; (b) dependent-marking.

\subsubsection{Degree of agglutination}

In the resulting patterns, after the grammaticalisation process reaches its conclusion, the dependency mark originating from PRON can vary its agglutination status from a free morpheme to a clitic and, finally, to a bound affix. For the sake of simplicity the agglutination status is assigned on a commonsensical 
ground and is not checked against any general criteria of cliticisation, since such criteria (e.g. Nevis and Joseph 1993: 94) are typically dependent on the speaker's grammatical intuition, which is not available in the case of dead languages. After all, few would deny that adjectival endings in Slavic and Germanic are totally bound, while the Greek article and Persian ezâfe are clitics.

The degree of agglutination is not necessarily correlated with the date of attestation. Thus, Old Slavic adjectival endings rapidly agglutinated already at the beginning of the written tradition, while Old Lithuanian adjectival endings never attained complete agglutination even up to the present day; Germananic strong adjectival endings enter the written tradition as already completely bound morphemes.

\subsubsection{Position of the mark}

The normal position of PRON (or the mark that originates from it) in the resulting patterns can be usually ascertained. For instance, the mark can be either preposed (as a prefix or a proclitic), or postposed (as a suffix or a "postclitic") to the stem it relates to. Note that, as already anticipated, the mark position is an independent value with respect to the strategy of marking: both dependent and head-marking languages can, in theory, have either preposed or postposed marks.

\subsubsection{Source of the mark}

The source pattern in Figure 1 includes a "pronominal element", symbolically indicated as PRON, but the specific etymological nature of this element, as well as its semantics, is subject to variation. Formally, PRON can arise from the following PIE pronominal stems:

(a) *io-/i-, as in Vedic, Avestan and Balto-Slavic (perhaps also in Armenian);

(b) *so, as in Greek, and, indirectly, in Old Persian;

(c) $* k^{w} i-k^{w} O-$, as in Hittite, Carian, Parthian, and plausibly in Armenian;

(d) an indeterminate short pronoun form, indistinguishable from pure pronominal terminations can be hypothesised for Germanic, Prakrits and Khotanese. 
Semantically, pronominal linkers can originate from demonstrative or, more often, relative pronouns. In many cases, such pronouns survive for some time as independent words before undergoing a complete grammaticalisation (see Probert 2015: §3.2.1): PIE *io- continues as an independent relative pronoun

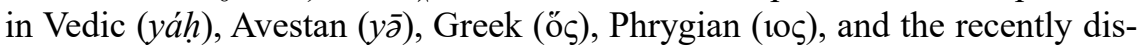
covered Celtiberian pronoun ios (Lejeune 1973: 646). ${ }^{3}$ To the athematic variant of the same stem, with a likely demonstrative meaning, can be ascribed Lithuanian $j i s$ and Slavic * $i$ (as well as Gothic is and Latin $i s$ ).

Pronominal stems deriving from PIE ${ }^{*} k^{w i}{ }^{w} /{ }^{*} k^{w} O$ - are also well-attested with the relative meaning in many IE languages, from Anatolian to Latin and Italic dialects (see a survey in Luján 2009; cf. also Dunkel 2014: 452), and perhaps also Armenian (see §2.4).

On the other hand, the PIE pronominal stem *so usually developed into demonstrative pronouns and is well-known in Vedic (sálsáh), Avestan $(h \bar{o})$, Greek (o), Gothic (sa), Tocharian B (se); see Dunkel (2014: 732). Old Persian haya seems to come from the concatenation of $*_{s o}$ with $*_{i o-}$, see Dunkel (2014: 318, fn. 36) and \$2.2.1 in the present study.

Finally, another possibility consists of attaching pronominal endings to nominal stems in order to form the so-called "strong declension" of the adjective (see $\S \S 2.6,2.8$ ). Such endings can be interpreted as originating from phonologically short pronouns, whose inflected forms consisted practically of the endings only. The Sanskrit demonstrative stem * $a$ - 'this, that' (attested as gen.sg asyá, dat.sg asmaí, etc.; cf. also Avestan $\bar{\partial}$ 'he') is one such short pronoun; it is referred to a primordial PIE pronominal stem $* e-/ o$ - by Dunkel (2014: 183). But also the inflected forms of the Slavic demonstrative *i (e.g. gen.sg jego, dat.sg jemu, etc.) are almost indistinguishable from their own endings.

\subsection{Two notes on semantics}

\subsubsection{Relative vs. demonstrative interpretation of pronouns}

The issue of the distinction between demonstrative and relative semantics of PRON is less crucial than it could seem. Diachronically, relative pronouns are

\footnotetext{
${ }^{3}$ Today, this pronominal stem is often reconstructed as $h_{2} i o-$ (see Dunkel 2014: 312 ), which is therefore distinguished from PIE *io having a conjunctional meaning (see Dunkel 2014: 384; contra Ivanov 1979: 55-56). The laryngeal is reconstructed on the ground of a very weak evidence limited to some Greek examples. Since it is not crucial, I am omitting the laryngeal in the present study.
} 
easily interchangeable with the demonstrative ones. Synchronically, they can be phonologically homonymic or very similar. At a syntactical level, the distinction between a relative clause and a paratactic construction is, sometimes, more stylistic than grammatical, cf. the two English sentences in (2).

(2a) This is the guy. I've known him since we were in college.

(2b) This is the man whom I have known since we were in college.

Similarly, in many contexts in Homeric Greek the distinction between a subordinate relative clause and a conjunction of two independent declarative clauses is quite weak and interpretation-based (some such cases are mentioned in $\S 2.3 .1){ }^{4}$

However, there is no need to deny the existence of relative clauses in PIE, as some scholars do (the hypotheses postulating such "primitive" syntax in PIE are surveyed in Probert 2015: Ch. 2). From the history of the attested IE languages we clearly observe that subordinating elements can be abandoned, substituted and renovated at a very high rate (as pointed out by Probert 2015: 16). This means that PIE could have had some other relative linker that has not survived as such in any of the daughter languages.

\subsubsection{Linking function vs. determinacy}

In analysing the evolution of this construction some scholars (including Benveniste 1966; Ivanov 1979; Probert 2015) focused on the functional burden of PRON, which seems related to the coding of some semantic/pragmatic content, such as determinacy, topicality, or restrictiveness. On the contrary, I am following the approach of those scholars (cf. Wissemann 1957; Seiler 1960; Kuryłowicz 1975; Franco et al. 2015) who consider PRON primarily a "syntactic linker" that serves the needs of signalling constituency, i.e. of keeping together head and modifiers. ${ }^{5}$ It was the linking function that initiated the whole grammaticalisation process. This is even more important in nonconfigurational languages, where the extreme flexibility of syntax needs to be compensated by a rich morphological marking of the constituency structure. The

\footnotetext{
${ }^{4}$ As an anonymous reviewer correctly reminds me, Old Indian used accentual means for differentiating dependent and main clauses: in the former the predicate was accented, while it was normally clitic in the latter. Indeed, the ambiguity I am speaking about here would be ruled out in Sanskrit. However, my claim still holds for Greek, where no such distinction is attested.

${ }^{5}$ Further references on pron as a linker are in Bakker (2009: 218) and Petit (2009: 349).
} 
other functions, so to say the "additional semantic burden", were less pivotal, which can be seen from the fact that, for example, there is no consistency, across and even within languages, in what determinacy values are expressed by PRON (see Orr 1983 on Balto-Slavic vs. Germanic determinacy status expressed by adjectives; see Evans 2019: §5.2.1 for a collection of examples of alternating determinacy status of adjectives in parallel Bible verses across Germanic languages).

\section{Analysis of data}

In this section the data will be presented within the parametrical framework described above. I start from describing the state of affairs in the 1st generation languages, for instance, Avestan and Vedic, since the oldest attestations of this innovation are observed precisely in the Old Indo-Iranian domain, and it is only in the Iranian area that it shows an interrupted history up to the present days. Subsequently, a series of 2nd generation languages are surveyed.

\subsection{First generation languages}

\subsubsection{Avestan}

Avestan presents a special syntactic construction which is widely known as "article-like relative" or "quasi-article" (see Caland 1891: §§24-51; West 2011: §§237-239). The element that functions as "quasi-article" is the pronoun $y \bar{z}$, going back to PIE *io-, and still functioning as a relative elsewhere in Aves$\tan$. A few grammaticalisation steps listed in $\S 1.3$ are observed here.

According to Seiler (1960: Ch. 4), two linear orders of the three elements predominate, in Avestan: HEAD PRON MODIFIER and PRON MODIFIER HEAD. This amounts to say that "quasi-article" is not usually separated from the quality modifier. Therefore, we can infer a dependent-marking strategy, even if it cannot be determined with absolute certainty due to the incomplete cliticisation.

The position of PRON, with respect to the quality modifier, is always preposed.

As often observed (cf. Haider and Zwanziger 1984: §2.3), the variety of case-forms in which the relative element could stand becomes richer in the diachrony of Avestan: limited to nominative and accusative in Gathic, extended to ablative and instrumental in Young Avestan. See the examples in (3), where the "quasi-article" is glossed REL. 
(3a) raoç̄bīš [...] yāiš Ahurahē Mazdå lights-INST REL-INST Ahura-GEN Mazdā-GEN 'with the rays of Ahura Mazdā' (Y. 58.6)

(3b) yōm Mazdąm Ahurəm REL-ACC Mazdā-ACC Lord-ACC 'the Lord Mazdā'/'Mazdā the Lord' (Y. 45.8)

(3c) vă $\quad[\ldots]$ yōṇg daēuuōṇg you-ACC $[\ldots]$ REL-ACC daēvas-ACC 'you, the Daēvas' ( $Y .32 .5)$

(3d) hača zəmat yat paӨanaiiå from earth-ABL REL-ABL wide-ABL 'from the wide earth' (Yt. 17.19)

In Avestan, however, this construction is optional, and identical phrases are attested both with and without the "quasi-article". Also, the correlative pronoun is sometimes preserved, see the phrase aom stāram yim tištrim "this star, the Tištrya' (Yt. 8.50; 8.52), which correlates the "quasi-article" to the demonstrative pronoun aom 'this'.

\subsubsection{Vedic}

A similar construction is also attested in Vedic, but here it presents even less signs of grammaticalisation than in Avestan. Thus, the case agreement of the relative element with its antecedent is usually lacking; the correlative pronoun is rarely omitted; the linear word order is highly variable, so no standard position of the relative pronoun can be determined. The claim, made by Benveniste (1966: 218), that it tends to be located after modifier does not appear substantiated by the data; cf. example (4d) vs. the others.

(4a) áditir $[\ldots]$ yấ $\quad$ duhitấ táva
Aditi-NOM

'Aditi, your daughter' (RV 10.72.5)

(4b) paúrușeyaṃ vadháṃ yám

human-ACC death-ACC REL-ACC

'death caused by men' (AV 19.20.1) 
(4c) brhát sváścandram ámavad yád

lofty-ACC self-luminous-ACC formidable-ACC REL-ACC

ukthyàm ákrṇvata bhiyásā róhaṇaṃ diváh

praiseworthy-ACC made fear-INST rising-ACC sky-ACC

'the lofty, self-luminous, formidable and praiseworthy, in fear they made him their means of ascent to heaven' (RV 1.52.9)

(4d) sấ rắtrī páritakmyā yấ

that-NOM night-NOM waning-NOM REL-NOM

'that waning night' (RV 5.30.14)

Unlike Iranian "quasi-article", the parallel Vedic pattern did not evolve into a fully grammaticalised construction in the later Indo-Aryan varieties. A rare Prakrit example is mentioned by Burrow (1937: §127), who describes verbless relatives governed by yo in Gāndhārī (the language of the Kharoșthi documents from Chinese Turkestan), see (5).

(5) yo iśa vartamana Lṕimsuasa paride ñadartha bhavidavo

REL-NOM here news-NOM Lṕimsu-GEN from learn must

'the news from here, you must ask Lṕimsu about them' (n. 165 in Burrow 1937)

It is difficult to establish the degree of naturalness of this construction, since this MIA variety is suspected of being an artificial learned language with many archaisms, see Burrow (1937: vi-vii). More on Prakrits in §2.8.2.

\subsection{Persian}

\subsubsection{Old Persian}

The Avestan "quasi-article" was paralleled also in Old Persian, even if PRON, in this case, is not etymologically identical with Avestan $y \bar{\partial}$. Depending on how we interpret the Achaemenid spelling $\left\langle\mathrm{h}^{\mathrm{a}} \mathrm{y}^{\mathrm{a}}\right\rangle$, this pronoun can be derived from two Proto-Iranian sources. It used to be read as hya (alternating with the stem tya- in the declension); accordingly, it was seen as an enlargement of the Indo-Iranian pronominal root $s$ - with the suffix -(i)ya-, parallel to Vedic $s(i) y a-$ 'that' (see Meillet 1915: §331). Today, it is rather read as hayaltaya- (see 
Strunk 1967; Schmitt 2014: 193; Dunkel 2014: 318, fn. 36); in this case, it should be interpreted as the concatenation of the Proto-Iranian demonstrative and relative pronouns, literally 'that, which'. Both interpretations, however, rule out the possibility of reconstructing a "quasi-article" already at the ProtoIranian stage.

Some examples can be observed in (6); the "quasi-article" is glossed as REL. The examples are chosen so that all possible types of modifier can be shown: appositions, as in (6a), (6b) and (6c); quality modifiers (so-called "adjectives"), as in (6d) and (6e); possessors in the genitive, as in (6f) and (6g). The head nouns to which this "quasi-article" agrees are usually in nominative, accusative, or genitive (see Meillet 1915: §§380-384).

(6a) Gaumāta hya maguš

Gaumata-NOM REL-NOM magian-NOM

'Gaumāta the magian' (DB I.65-66)
Bardiya amiy hya Kurauš
puça
Bardiya-NOM am REL-NOM Cyrus-GEN
son-NOM
'I am Smerdis, the son of Cyrus' (DB IV.9)

(6c) Dārayavauš hya manā pitā

Darius-NOM REL-NOM I-GEN father-NOM

'Darius my father' (XPf 30-31)

(6d) martiya hya draujana

man-NOM REL-NOM liar-NOM

'the lying man' (DB IV.38)

(6e) xšāya

king-NOM lands-GEN REL-GEN many-GEN

'king of the many lands' (DPe 3-4)

(6f) hyā amāxam taumā

REL-NOM we-GEN family-NOM

'the family of ours' (DB I.8)

(6g) kāra hya manā avam kāram tyam

army-NOM REL-NOM I-GEN this-ACC army-ACC REL-ACC

vahyazdātahyā aja

Vahyazdāta-GEN defeated

'My army defeated this army of Vahyazdāta' (DB III.45) 
With respect to Avestan, the Old Persian "quasi-article" appears one step further on the grammaticalisation scale; however, it is still far from being completely agglutinated to the preceding word; for instance, it is always separated by the word separation mark, in the Achaemenid inscriptions.

In most of the occurrences, the word order within the NP is HEAD PRON MODIFIER (see Seiler 1960: 131); but notice the exception in (6f), where the order is reversed: PRON MODIFIER HEAD. The modifier can be separated from the head noun, as in (6b), but it is never separated from the "quasi-article", and the latter is always preposed to the former. As in Avestan, the dependent-marking strategy can be foreseen here, which is, however, contrasted by the outcomes of this construction in Middle and New Persian.

\subsubsection{Middle and New Persian}

The Old Persian "quasi-article" construction is apparently continued in the Middle Persian construction which can be similarly termed "quasi-ezäfe". The PRON element evolved here into a dependency marker that is cliticised to the head NP. It is spelled ‘'y〉 and ' $y g$ 〉 and read as $\bar{l}$ and $\bar{l} g$, respectively (or $i$ and $i g$, according to Nyberg 1964-1974: II, 105). The longer form is an enlargement of the shorter, with no apparent differentiation in the grammatical value. Formally, Middle Persian $\bar{l}(g)$ seems to derive from the Old Iranian relative pronoun (see Durkin-Meisterernst 2014: §439).

In the older sources this "quasi-ezäfe" can still be found in its original function of a plain relative pronoun, and, on the other hand, the nominal modifiers can also lack this linking element in some contexts. However, in later texts, it appears almost as grammaticalised as the New Persian ezäfe (see Haider and Zwanziger 1984: §3; Durkin-Meisterernst 2014: §531). Consequently, it is glossed EZ in (7) and (8); example numbers are from DurkinMeisterernst (2014).

(7a) $\bar{o}$ wimand $\overline{1}$ xūzestān

to border EZ Khuzestan

'to the border of Khuzestan' (2)

(7b) rah dō $\overline{1}$ xwar ud māh

chariot two EZ sun and moon

'the two chariots, that is, the sun and the moon' (38) 
(7c) iškōhān $\overline{1}$ ba az dānišn $\quad \overline{1}$ yazdān poors EZ without knowledge EZ gods 'the poor without the knowledge of gods' (45)

(7d) āštānag $\overline{1}$ naxwistēn threshold EZ first 'the first threshold' (45b)

Note that Middle Persian "quasi-ezāfe" is not restricted to one specific type of modifier, be it a possessor (7a), an epithet (7b), a quality modifier, i.e., an "adjective", (7d), or a prepositional phrase (7c). It is a clitic rather than an ending, in that it is attached to a phrase, rather than to a word, as can be seen in (7b) where it modifies rah $d \bar{o}$ 'two chariots', i.e. a whole NP. Another innovation, with respect to Old Iranian, is that it allows recursive nesting of one modifier into another, as happens in (7c).

Notice that a similar construction is also attested in Parthian, whose ezāfe morpheme $\bar{c} \bar{e}$ originated from the Old Iranian interrogative pronoun, going back to the PIE pronominal stem $* k^{w i} i$; see examples in (8).

(8a) tōhm čē amāh

family EZ ours

'our family' (23)

(8b) srōd čè šādīft

song ez joy

'the song of joy' (24)

The last step towards the complete grammaticalisation of the ezāfe has been taken in New Persian. Two examples (from Haider and Zwanziger 1984: 160) are given in (9); the ezâfe morpheme $-i$ is glossed EZ.

(9a) lab i la'1

lip EZ ruby

'a ruby lip'

(9b) la'1 i lab

ruby EZ lip

'the ruby of the lip' 
As the two NPs in (9) clearly show, a New Persian nominal can function either as a head, or a modifier, according to the context. As in Middle Persian, the ezāfe morpheme is a phrasal clitic, not a nominal ending.

It can be also added that in Kurdish, another Modern Western Iranian variety, more conservative than New Persian, the analogous ezâfe particle still agrees in gender and number with the head noun (see Petit 2009: 344; Franco et al. 2015: §3.2).

To sum up, from Middle Persian on, the ezāfe remains the only constituency marker for the nominal phrase, which, after the loss of most of the Old Iranian nominal inflections and the consequent restructuring of the whole syntactic system, shows also a rigid fixation of the word order (cf. Haider and Zwanziger 1984: §3).

\subsection{Greek}

\subsubsection{Two competing pronominal elements}

The situation in Greek can be proven analogous to the one attested in Avestan and Old Persian. It is partly complicated by the fact that two different pronominal stems were competing for the same function of PRON: the demonstrative pronoun $\dot{o}, \dot{\eta}, \tau$, , going back to PIE ${ }^{*} s o,{ }^{*}{ }^{s e h} h_{2}{ }^{*} t o d$, and the relative pronoun ös, ๆ̆, ö, from PIE *ios, *ieh ${ }^{*}{ }^{*}$ iod. The verbless relative construction is attested in Preclassic Greek with both of these two pronouns.

Notice that these two sets of pronominal forms were phonetically undistinguishable in a part of the paradigm, being differentiated in spelling only in a later period. In Homer, the two pronouns have no clear difference in meaning either, as they appear in identical contexts (see Probert 2015: Ch. 11). Therefore, their qualification as relative vs. demonstrative is partly conventional and reflects a later standardisation.

In Homer (but also in Hesiod, Herodotus, Pindar, and Attic Tragedy), indeed, we find examples of ó, $\dot{\eta}$, $\tau$ ó used as a relative pronoun (noticeably, always in postnominal position, see Chantraine 1942-1953: II, 167). Some examples are available in (10), where the "relative o" is glossed DEM>REL.

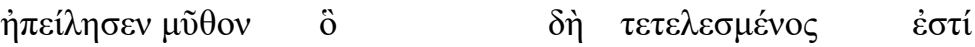
kept word-ACC DEM>REL-nom now accomplished-NOM is 'he uttered the word that now has come to pass' (Il. 1.388) 


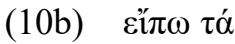

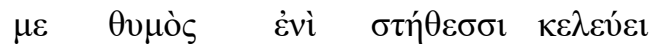
say DEM>REL-ACC I-ACC mind-NOM inside breast-DAT bid 'I may say what the heart in my breast biddeth me' (Il. 8.6)

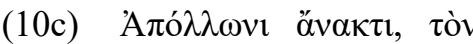

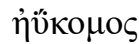
$\tau \varepsilon \dot{\kappa \varepsilon} \Lambda \eta \tau \omega ́$ Apollo-DAT lord-DAT DEM $>$ REL-ACC fair.haired-NOM bore Leto-NOM 'to the lord Apollo, whom fair-haired Leto bore' (Il. 1.36)

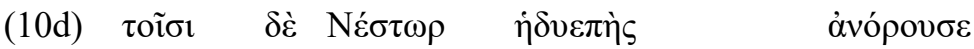
they-DAT and Nestor-NOM sweet.speaking-NOM sprang

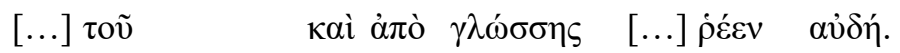
DEM>REL-GEN and from mouth-GEN flowed voice-NOM

'And among them sprang up sweet-speaking Nestor [...] from whose mouth the voice flowed [...]' (Il. 1.247-9)

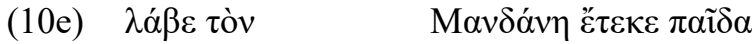

take DEM>REL-ACC Mandane bore child-ACC

'take the child whom Mandane bore' (Hdt. 1.108.4)

Quite often, as Humbert (1960: §54) remarks, the relative reading of $\dot{0}, \dot{\eta}, \tau o ́$ is only a question of interpretation. Thus, in (10c) the presumed relative tòv, in the accusative, could have also been translated as a demonstrative, provided that we read the clause as independent, rather than a subordinate one (imagine it preceded by a plain stop, instead of a comma). Similarly, with the genitive $\tau$ oṽ in (10d). On the contrary, the demonstrative reading in (10e) is ruled out by the fact that the relative is embedded inside the main clause.

The opposite is also true: a few instances of ö $\zeta$, $\dddot{\eta}$, ö used as a demonstrative are known in Homer, and, limitedly to such idioms as ö $\varsigma \alpha a ̀$ ö $\varsigma$ 'such and such a person' or the sentence-initial kaì ö $\varsigma$ 'and he', also in the Koiné. See some examples in (11), where this "demonstrative ö $\zeta$ " is glossed REL〉DEM.

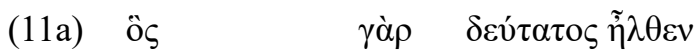

REL $>$ DEM-NOM indeed last-NOM went

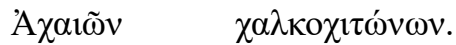

Achaeans-GEN brazen.coated-GEN

'for he was the last of the Brazen-coated Achaeans to reach home' (Od. $1.286)$ 
(11b) $\mu \eta \delta$ ' òs $\quad$ v́์

and.not REL`DEM-NOM escape

'and not even he shall escape' (Il. 6.59)

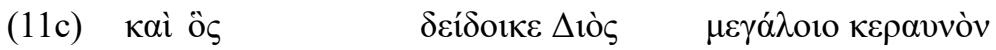

and REL $>$ DEM-NOM fears Zeus-GEN big-GEN lightning-ACC

'even he has fear of the lightning of great Zeus' (Il. 21.198)

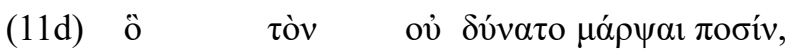
this-NOM that-ACC not be.able reach feet-DAT,

oủ $\delta$ òs $\dot{\alpha} \lambda \hat{\xi} \xi \alpha$.

and.not REL`DEM-NOM escape

'one could not catch the other with his feet, and the other could not escape' (Il. 22.201)

Note that in the those case-forms where the two pronouns have different shapes, the relative vs. demonstrative interpretation is sometimes guaranteed by the metre; for example, in (10a) ô $\delta \grave{~ c a n n o t ~ b e ~ e m e n d e d ~ i n t o ~ o ̂ s ~} \delta \grave{\eta}$ because

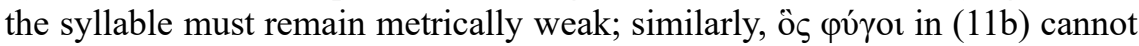
be emended into ô púfor because the syllable must remain metrically heavy.

After a period of competing distribution only one of the two pronouns, i.e. the demonstrative $\dot{o}, \dot{\eta}, \tau$ ó, underwent the complete grammaticalisation and became the plain definite article in Classic Greek (and later), while ö $\zeta$, functioned only as a relative linker. Interestingly, in those dialects where the article never emerged, o has completely ousted ós in the function of the relative pronoun, see Chantraine (1942-1953: I, 277) and Probert (2015: 121).

To some extent, Greek article can be considered, as suggested by Vaillant (cf. 1942: 5), the result of the merger of these two pronominal stems. Indeed, in the diachrony of Greek they became progressively more similar, while distinctive allomorphs were soon abandoned (such as Homeric plurals toí and $\tau \alpha$ í, related to ó and $\dot{\eta}$, but not to ö $\varsigma$ and $\eta$ ). Moreover, they were sometimes

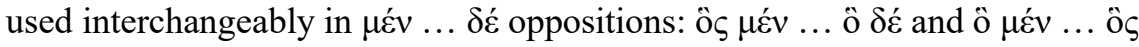
$\delta \varepsilon \dot{\varepsilon}$ are both attested.

It could be added that the term ó $\rho \theta \rho o v$ 'joint' of the Ancient Greek grammatical tradition - upon which the Latin term articulus 'article' was later calqued - was initially used for both the relative and the demonstrative pronouns (see Schwyzer and Debrunner 1939-1950: II, 14). This seems to point to the fact that they were somewhat perceived as very similar, if not identical, 
elements in the Greek speakers' linguistic intuition. This terminology survives even in Liddell and Scott's Lexicon, where the relative ö $\varsigma$, "postpositive article".

\subsubsection{From verbless relative to article}

Importantly for the present study, both pronouns allowed verbless relative constructions in the attributive postnominal position. The relative ö $\varsigma$, lel to the similar use of the relative $y \bar{z}$ in Avestan - was, however, quite rare in this function, while $\dot{o}, \dot{\eta}, \tau$ co predominated in Homeric Greek and became the only possibility in Classical Greek.

Some of the rare examples with ö $\varsigma$, provided in (12). Note that the case agreement of the PRON element with the head noun is not attested in this construction: in $(12 \mathrm{a}-\mathrm{c})$ the head nouns are in the nominative anyway, so the agreement is not detectable, while in (12d) and (12e) it is clearly lacking.
Tẽ̃кро́s $\quad \theta^{\prime}$ ös
äpı

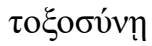

Teucer-NOM and REL-NOM best-NOM Achaeans-GEN archery-DAT 'and Teucer, best of all the Achaeans in bowmanship' (Il. 13.313-4)

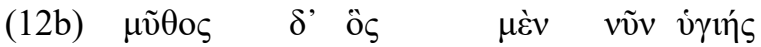
word-NOM but REL-NOM indeed now healthy

'but the word that is indeed good for today' (Il. 8.524)

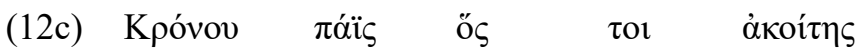

Kronos-GEN son-NOM REL-NOM you-DAT consort-NOM

'the son of Kronos, your consort' (Il. 15. 91)

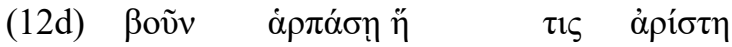

cow-ACC took REL-NOM some best-NOM

'took the cow that was the best' (Il. 17.62)

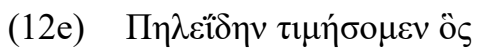

Peleus' son-ACC honour

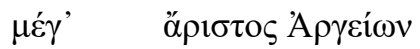

REL-NOM greatly best-NOM Argives-GEN

'we honour the son of Peleus, who is far the best of the Argives' (Il. 16.271) 
Examples from Homer and Herodotus with ó, $\dot{\eta}, \tau$ ć as PRON (glossed as ART) are provided in (13) below. Here, the agreement of PRON with the head noun is clearly detectable in the examples (13c) and (13e), where they both are in dative, and in (13f), where they are in accusative; in (13f) the quality modifier is a prepositional phrase.
(13a)

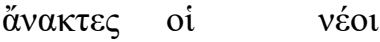
lords-NOM ART-NOM young-NOM
'the young masters' (Od. 14.61)

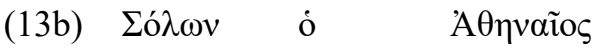
Solon-NOM ART-NOM of.Athens-NOM
'Solon of Athens' (Hdt. 5.113.2)

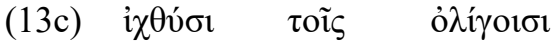
fishes-DAT ART-DAT little-DAT
'to the little fishes' (Od. 12.252)

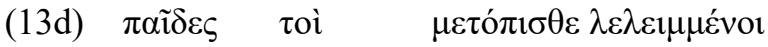
sons-NOM ART-NOM behind left-NOM
'the sons that have been left behind' (Il. 24.687)

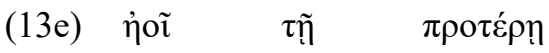
dawn-DAT ART-DAT first-DAT
'on early morning' (Il. 13.794)
oỉkń $\mu \alpha \tau \alpha \quad[\ldots] \tau \dot{\alpha} \quad \dot{\varepsilon} \pi \grave{\imath} \tau \tilde{\omega} v \quad \dot{\alpha} \gamma \rho \tilde{\omega} v$
dwellings-ACC $[\ldots]$ ART-ACC on ART-GEN fields-GEN
'the dwellings in the fields' (Hdt. 1.17.2)

Soon after Homer, the use of ö $\varsigma$, $\eta$, ö as PRON became obsolete. At the same time, $\dot{o}, \dot{\eta}$, , ó evolved into a plain article, almost completely losing its demonstrative meaning. In summary, the innovation under consideration here generated, in Early Greek, two competing constructions, using two very similar pronominal stems as PRON, but only one of them underwent complete grammaticalisation as a definiteness marking article, while its function as a constituency linker was gradually loosened.

\subsubsection{Three patterns of dependency marking in Greek NP}

The resemblance of the Greek construction to the Old Persian "quasi-article" must be highlighted. Both languages present a low degree of agglutination of 
PRON. Both mark the modifier with a preposed pronominal element. Such element in both languages refers to two different pronominal stems: in Old Persian they merge into one stem, while in Greek one ousted the other. Some constructions presenting the linear order HEAD PRON MODIFIER are strikingly similar, as can be seen from the comparison of the Greek examples in (13) with the Persian ones in (6).

However, some relevant differences are also detectable. An innovation specific to Greek is the redundant - or "polydefinite", cf. Franco et al. (2015) - marking of dependency with a repeated article. Traditionally, Classical Greek attributive constructions are classified into three stylistically conditioned orderings. ${ }^{6}$ They are the following:

1. $\quad$ ART MODIFIER HEAD (e.g.: ó $\dot{\alpha} \gamma \alpha \theta$ ò $\left.\alpha^{\prime} v \eta ́ p\right)$;

2. ART HEAD ART MODIFIER (e.g.: ó ỏvì ó $\alpha \gamma \alpha \theta$ ós);

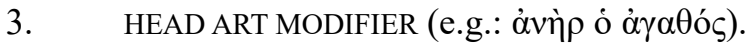

Patterns 1 and 3 appear dependent-marking. Pattern 2, instead, shows the redundant doublemarking strategy, since both the head and the modifier are preceded by the article. It is interesting to observe the diachronic distribution of the three patterns. Pattern 2 appears to be a later innovation, while pattern 3 seems an archaism, not unusual in the oldest stages of the language, but less and less attested in subsequent authors. The estimations from Gildersleeve (1900-1911: §609) are summed up in Table 1.

Table 1. Three articulated patterns in Greek.

\begin{tabular}{|c|c|c|c|}
\hline & 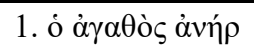 & 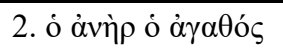 & 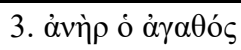 \\
\hline Homer & frequent & none & common \\
\hline Tragedy & \multirow{4}{*}{ predominant } & & \multirow{3}{*}{ some } \\
\hline Thucydides & & few & \\
\hline Heredotus & & some & \\
\hline Xenophon & & some & -fert \\
\hline Aristophanes & \multirow{2}{*}{ major } & common & - \\
\hline Attic oratory & & frequent & none \\
\hline
\end{tabular}

\footnotetext{
${ }^{6}$ This tradition goes back to Aristotle and is maintained intact by such modern scholars as Gildersleeve (1900-1911); see some criticism in Bakker (2009: 12-13).
} 
Interestingly, pattern 3 resurfaces, especially in NPs headed by proper names, in the New Testament; see the examples in (14).
$\mu \varepsilon \tau \alpha \grave{~ ' I \eta \sigma o v ̃ ~} \quad \tau 0 \tilde{v} \quad \Gamma \alpha \lambda \imath \lambda \alpha i_{0}$
with Jesus-GEN ART-GEN Galilean-GEN
'with Jesus of Galilee' (Mt. 26:69)

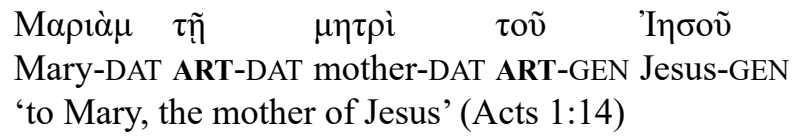

\subsection{Armenian}

Classical Armenian underwent a substantial influence from the Middle Iranian contact languages.

Accordingly, the Armenian verbless relative construction has been explained as a calque on the Middle Iranian "quasi-ezāfe" construction; see examples in (15).

anun Astucoy or tearn $\mathrm{n}$ araracoc'
name-NOM God-GEN REL-NOM lord-GEN DET creatures-GEN
'the name of God, the lord of creation' (EK $\$ 358)$

(15b) hogi mardoy $\mathrm{n}$ or i nma spirit-NOM man-GEN DET REL-NOM in he-LOC 'the spirit of the man, the one in him' (1 Cor. 2:11)

The etymology of Armenian relative stem or is debated. Meillet (1906-1908) considers it a possible outcome of PIE $* k^{w} O$-. The loss of the word-initial labiovelar stop is difficult to explain, but it is paralleled by some other pronominal derivatives. Instead, Pisani (1950) relates it to PIE *io-, on the basis of other examples of word-initial deletion of PIE $* i$ - in Armenian.

Notice that here the PRON is clearly a constituency linker, since the determinacy is autonomously marked by the clitic article $-n$.

Meyer (2017: §5.1.5) observes that the data at our disposal are insufficient to determine whether the Armenian verbless relative construction was a direct calque on the Middle Iranian "quasi-ezā $f e$ ", or an independent development of an inherited PIE pattern. Given that the present paper rejects the inheritance 
hypothesis in general, the real question to ask becomes the extent to which the Armenian construction is independent of its Iranian parallel. In both cases, however, the main result is that Armenian data must be considered part of the isogloss under consideration.

\subsection{Slavic}

The PRON element in Slavic was represented by the pronominal stem $j \grave{l}$ (spelled $i$ ), ja,je, which is also attested in autonomous use, either as a personal or relative pronoun (Večerka et al. 1994: 245). In its relative function it is normally enlarged with -že (iže, jaže, ježe), while, as a personal pronoun, it appears in all declensional cases except for the nominative, which is supplied by another pronominal stem (namely, on $\breve{u}$, ona, ono). As often noted (Petit 2009: 350; Wissemann 1957: 62-63), the strong reduction of the word-final consonantism in Proto-Slavic prevents us from establishing the exact etymon of $j i$ : it could be an outcome of either a thematic $\left({ }^{*} i o-\right)$ or an athematic $\left({ }^{*} i-\right)$ PIE pronominal stem, or even a merger of the two.

This pronominal element, agglutinated directly to the inflected nominals, formed the so called "long" or "plain" adjectives, as opposed to the simple adjectives, which still survive in many of these languages (they are called "short" adjectives in the Russian tradition).

Before the agglutination of PRON, as Old Church Slavonic material shows, there was no paradigmatic morphological distinction between nominal and adjectival declension (though nominal suffixation could perform the adjectivising function). Thus, drugŭ could be interpreted as either a noun, 'friend', or an adjective, 'other', according to the context of occurrence (Polivanova 2013: $\S 268$ ). The creation of the "long" adjectives served precisely the need of solving this ambiguity.

After PRON agglutinated completely to the nominal stems, the "short" adjectives rapidly became obsolete. Among modern languages, only some Southern Slavic varieties conserve a limited declensional paradigm of the "short" adjectives (see Parenti 1996: 38); in Russian, it is limited to the nominative only; in Western Slavic it disappeared completely.

The distribution of the "long" adjectives, with respect to the "short" ones, in the oldest Slavic texts is governed by semantic/pragmatic rules that are almost impossible to detect. The category of definiteness might have played some role in this respect, yet there is hardly any consistency in parallel passages from different manuscripts, and even within a single text. 
In the oldest sources, the nominal stem and the PRON were both fully inflected, which proves a certain degree of autonomy of PRON in the oldest stages of Slavic. As the process of agglutination advanced, the initial $/ \mathrm{j} / \mathrm{of}$ the PRON element underwent phonological erosion, generating a hiatus (which is usually prohibited by the phonotactics of Old Church Slavonic). At the last stage, the hiatus was abbreviated, which led to the complete fusion of the two endings into one (see on this Polivanova 2013: §394). All the stages are effectively attested, sometimes even within one and the same manuscript. Some examples are provided below; the adjectival markers are glossed ADJ, while the plus sign in the glosses indicates an incomplete agglutination.

(16a) mati bo blagodětijo byvaješi osǫždenujemu mother indeed grace-INST are convict-DAT+ADJ-DAT 'you are, by grace, the mother of the convict' (Suprasliensis 251.10-11)

(16b) dobraago sŭkrovišta good-GEN+ADJ-GEN treasure-GEN 'of the good treasure' (Assemanius, Mt. 12:35)

(16c) dobrago sŭkrovišta good-ADJ-GEN treasure-GEN 'of the good treasure' (Marianus, Mt. 12:35)

The example (16a) attests the oldest, unmerged form, in the dative; in the genitive in (16b) the intervocalic / $\mathrm{j} /$ has been already elided, with the consequent hiatus and vocalic assimilation; in (16c) the hiatus has been contracted, so that the original nominal ending $-a$ is not detectable anymore, while -ago functions as a completely agglutinated adjectival ending.

A certain autonomy of PRON in the oldest texts is suggested by cases of conjunction reduction: there are examples of conjoined adjectives, only one of which (usually the first) bears the adjectival marker; see (17).

(17a) vŭpadǔšaago vĭ razboiniky i prěžrěna fallen-ACC + ADJ-ACC among thieves-ACC and unconsidered-ACC 'the one who fell among the thieves and was forgotten' (Suprasliensis 329.28)

(17b) strašinumu i otŭemljoštju fearsome-DAT+ADJ-DAT and away-taking-DAT 'to him that is fearsome and that takes away' (Psalterium Sinaiticum, Ps. 75.13) 
vidę člověčĭsky dobryję ženy

seeing human-ACC good-ACC+ADJ-ACC wives-ACC

'seeing the good wives of men' (Suprasliensis 7.18-19)

Vaillant (1942) has collected a series of occurrences of Slavic PRON functioning as a phrasal clitic, rather than an ending, constructed with numerals, adverbs and whole prepositional phrases. Often, the preposition involved is bez 'without' (plus genitive), rendering the "alpha privative" of the Greek original.

(18a) na bezŭ ratii mir against without fight-GEN+ADJ-ACC peace-ACC 'against the peace without war' (Suprasliensis 324.22)

(18b) desętii negodovašę ten-NOM+ADJ-PL.NOM outraged 'the ten were moved with indignation' (Marianus, Mt. 20:24)

(18c) o izdrailju bez uma i oh Israel-VOC without mind-GEN.SG ADJ-VOC.SG 'oh, mindless Israel!' (Suprasliensis 387.7)

(18d) demona poludǐněego demon-GEN noonday-GEN+ADJ-GEN 'of the noonday demon' (Psalterium Sinaiticum, Ps. 90:6)

(18e) bes čina je množistvo without order-GEN ADJ-ACC multitude-ACC 'the unordered crowd' (Suprasliensis 322.20)

The sequence bezú rati+i in (18a) is the translation of the Greek adjective

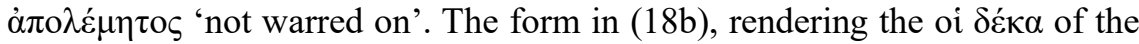
Greek original, is a nominative plural of desęt ' ' 10 ', followed by $i$ (nom.pl of $* j i)$. The prepositional phrase bez uma is followed by a vocative form of $* j i$ in (18c), which produces an otherwise prohibited hiatus, so the editor inserted a word separation before it. In (18e), rendering Greek ó $\tau \alpha \kappa \tau o v ~ \pi \lambda \eta \theta$ v́v 'unordered crowd', the neuter accusative $j e$ follows another prepositional phrase with bez.

Summarising the situation in Slavic, we can observe that the process of grammaticalisation of PRON went quite far, but was not yet fully accomplished 
at the time of the first attestations. The source of PRON is io- (or its athematic counterpart $i$-); the strategy of marking is dependentmarking (since it is affixed on the adjectives), and the position of mark is suffixal. Since the linear order is quite free in Slavic, it is difficult to make generalisations regarding the resemblance to the pattern attested in Old Persian, Avestan and, in part, Greek (cf. Wissemann 1957).

\subsection{Germanic}

Germanic languages, already in the oldest documentation, present a well-established system of two parallel adjectival declensions: the so-called "weak" and "strong" adjectives. The former probably derive from the declension of the nominal stems in nasal (see the survey in Orr 1983: 110); the latter, on the other hand, exhibit clearly pronominal endings in most of the forms. Typologically, Germanic "strong" adjectives are often considered parallel to the pronominalised adjectives in Slavic and, for the transitive property, to the other languages under consideration (cf. §3).

All Germanic languages have also developed a new definite article, going back to PIE pronominal stem *so/to-. This led Ivanov (1979: 62), who was exclusively concerned with the relative pronoun in its function of a definiteness marker in Slavic and other IE languages, to excluding the Germanic data from his study. However, the Germanic article seems to be a late innovation, not yet fully grammaticalised in the earliest extant texts (such as Biblical Gothic, where the presumed article still behaves as a demonstrative pronoun in many occurrences), and totally lacking in the oldest Runic inscriptions; for more evidence see Orr (1983). In the present paper, on the other hand, PRON is considered primarily a constituency linker and is not necessarily derived from a relative stem. Therefore, I see no grounds for excluding a priori the Germanic "strong" adjectives from our analysis. If not etymologically, they are connected to the isogloss under consideration at least for typological reasons: the "strong" adjectives represent an innovative declensional type which defines the adjective as a lexical class (as opposed to noun).

The distribution of two forms of adjectives in Germanic is clearly aligned along the definiteness opposition, which is easily detectable thanks to the article. Thus, the "strong" adjectives in Gothic rule out the article (with rare exceptions); the weak adjectives do usually require the article, even if not as strictly as was commonly believed (cf. Ratkus 2018). 
Interestingly, the "strong" vs. "weak" adjectives distribution in Germanic appears reversed with respect to that of the "long" vs. "short" adjectives in Slavic (provided that the latter can be detected at all). The adjectives with pronominal endings in Germanic are used as indefinite, while similarly pronominalised adjectives in Slavic are definite.

In (19) three examples from Gothic are quoted; "strong" endings are glossed with STR followed by the case gloss, while "weak" endings are only glossed for case; note that the declension of articles and pronouns is automatically "strong".

hlaif unsarana pana sinteinan gif uns bread-ACC our-STR.ACC the-STR.ACC daily-ACC give we-DAT 'Give us our daily bread' (Codex Argenteus, Mt. 6:11)

atgiban pana swaleikana unhulpin

deliver the-STR.ACC such-STR.ACC devil-DAT

'to deliver such a man to the devil' (Codex Ambrosianus A, 1 Cor. $5: 53)$
(19c) allata
galaubeip, all- $\varnothing$
weneip
all-STR.ACC believes, all-STR.ACC hopes
'believes all, hopes for all' (Codex Ambrosianus A, 1 Cor. 13:7)

In (19a) a definite NP headed by hlaif is modified by both a "weak" adjective and a possessive pronoun, obviously with a "strong" ending. The phrase in $(19 b)$ is interesting in that it presents one of the few adjectives that remain "strong" even when preceded by the article. The passage in (19c) presents one zero-marked and one openly marked "strong" ACC.SG.N ending.

It has been long established that "strong" endings are pronominal in nature. As a working hypothesis, I consider them the result of agglutination of a phonologically short pronominal stem, possibly from PIE $* e-/ o-$, to the nominal stems. Other agglutination hypotheses have been around for almost two centuries, but have never been widely accepted; they were dismissed, for example, by Sievers (1876) and Leskien (1876: 138), but later proposed again, see the survey in Bammesberger (1990: §10.2.2.5).

The alternative view posits that the "strong" endings were simply transferred from the pronominal declension to the adjectives, possibly by lexical diffusion (cf. Ratkus 2015). A conciliatory approach appears in Prokosch (1939: 261): on one hand, in stressing the parallelism with Baltic and Slavic 
pronominalised adjectives, he claims that the "strong" declension adds pronominal elements; on the other hand, he describes the resulting endings as having transferred from the pronominal declension.

The agglutination hypothesis presents some weaknesses.

(a) Only some of the "strong" endings, with even some language-specific variance, appear unambiguously pronominal, while others can be also explained as nominal (the assumption is that, if agglutination had ever occurred, it should have involved all case forms).

(b) It is usually taken for granted that an agglutinated pronominal form should have developed from PIE relative *io- (cf. references in Sievers 1876: 99). But where would the initial $j$ - of such pronoun have gone in this intervocalic environment? No traces of $/ \mathrm{j} /$ are observable in the "strong" declension.

(c) Bare adjectives, similar to Slavic "short" adjectives, are not attested in Germanic.

I think that agglutination hypothesis is still tenable, and its weaknesses can be overcome. Firstly, as proposed in McFadden (2004), all of the "strong" endings, not just some of them, can be explained as pronominal (this reconstruction has not been accepted by all specialists, see the criticism in Ratkus 2015: $\S 3.6)$.

Secondly, the bare, nonpronominalised adjective does effectively exist in Gothic, even albeit only in one case-form, i.e. the zero-marked NOM/ACC.SG.N., cf. the example in (19c). But this strong limitation appears less problematic if we remember that, for example, the "short" adjectives in Russian are likewise limited to the nominative form only.

Finally, and most importantly, the relative *io- stem is not the only possible source of PRON. I think that postulating ${ }^{*} o-/ e$ - as the source is a way to reconcile the two hypotheses: as long as the pronominal wordforms are identical to their own endings, the difference between transfer and agglutination becomes unsubstantial. The relevant result of this process was that it produced a special declensional type defining the adjectives as a lexical class (cf. Bammesberger 1990: 228). That we have no direct attestation of such pronouns in Germanic could be perceived as a problem. However, the outcomes of PIE ${ }^{*} o-/$ $e$ - are known in the other daughter languages (see Dunkel 2014: 183ff.). One such example is Sanskrit demonstrative pronoun usually denoted by its neuter 
nominative form idám 'this, that', which is effectively undistinguishable from its own declensional endings: genitive asyá, dative asmaí, locative asmín, etc.

\subsection{Baltic}

\subsubsection{The "definite" adjectives}

The Baltic languages also exhibit grammaticalisation of the PRON construction. In Lithuanian, for example, the inflected pronominal element $-i s,-j i$, almost identical to the anaphoric pronoun $j i s, j i$, is added to inflected adjectival stems (unlike in Old Church Slavonic, the adjectival declension does not match the nominal one in that it adopts pronominal endings for some caseforms; see Dini 2014: §2.2.1.7). The etymology of this pronominal element is debated; see Petit (2009: §3). It could be an outcome of the PIE relative stem *io- alone (as Delbrück and many others after him believed), or a blending of *io- with the demonstrative * $i$ - (see Rosinas 1975; cf. Wissemann 1957).

The resulting adjectives are often called "definite" since they appear somehow related to the category of definiteness. However, their distribution is, once again, difficult to formalise, especially in the oldest attestation of Lithuanian. Parenti (1996: 29) quotes parallel verses of three modern Lithuanian translations of the New Testament which present impressive variability in the use of "definite" vs. simple forms of the same adjectives in parallel passages. ${ }^{7}$

Two examples in Modern Lithuanian are provided in (20); the pronominal element is glossed ADJ and is separated by the plus sign in order to symbolise its incomplete agglutination. Note that the noun phrase in (20a) is an idiom; if the adjective is used in its simple form, the meaning changes: aukšta mokykla 'a high school-building'.

$$
\begin{aligned}
& \text { aukštoji mokykla } \\
& \text { high-NOM+ADJ-NOM school-NOM } \\
& \text { 'the university' }
\end{aligned}
$$

$$
\begin{aligned}
& \text { paduok aštrujj } \quad \text { peili } \\
& \text { give sharp-ACC+ADJ-ACC knife-ACC } \\
& \text { 'pass me the sharp knife' }
\end{aligned}
$$

\footnotetext{
${ }^{7}$ However, in Modern Lithuanian definiteness is undeniably a component of the meaning of this morphological category; see Ratkus (2018: §3).
} 
Some Old Lithuanian examples are presented in (21); the orthography of the originals has been preserved. They all present some archaic features which are discussed in $\S 2.7 .2$.

(21a) żaisła paioprasta toy-GEN PREF+ADJ-GEN+simple-GEN

'of the simple toy' (Petkevičius' Catechism 98.16)

(21b) awineła ne iokaltoia lamb-GEN NEG ADJ-GEN+guilty-GEN+ADJ-GEN 'of the innocent lamb' (Knyga Nobažnystès 1.258.16)

(21c) tikras ir teisusis kunas true-NOM and righteous-NOM+ADJ-NOM body-NOM 'true and righteous body' (Mažvydas' Catechism 25.15)

(21d) tikrospiosp wienibesp true-GEN-ALL+ART-GEN-ALL unity-GEN-ALL 'to the true unity' (Mažvydas' Catechism 207.1)

(21e) tikromįsiomis awêłemis true-PL.INST+ADJ-PL.INST sheep-PL.INST 'with the true sheep' (Daukša's Postilla 249.8)

(21f) tewuy danguieiam god-DAT heaven-LOC-ADJ-DAT

'to the God in heaven' (Petkevičius' Catechism 250.9)

2.7.2. Some difficulties and an alternative view

Though similar to the Slavic "long" adjectives, Baltic "definite" adjectives present a series of characteristics that differentiate them strongly enough to make the hypothesis of a common Balto-Slavic origin appear untenable. The main issue is chronological: at the time that the grammaticalisation of PRON is nascent in Baltic, it is already fully accomplished in Slavic. Other pieces of evidence for this claim are summarised in what follows.

(a) Examples of "definite" adjectives in Old Prussian, the oldest attested Baltic language, are extremely limited and uncertain; only nominative and accusative forms are registered by Trautmann (1910: §167). 
(b) The agglutination of PRON took place separately in Lithuanian and Latvian, as some accentual facts suggest (more details in Zinkevičius 1958: $52-53)$.

(c) The adjectival endings are almost fully preserved when followed by PRON; even the bisyllabic case endings, which undergo phonological reduction in the modern language, are still intact in Old Lithuanian; see (21e) where the form tikromisiomis 'with the true' (INST.PL) corresponds to a shortened form in Modern Lithuanian: tikrosiomis.

(d) The agglutination postdated the creation of word-final locative markers in Old Lithuanian. Thus, in (21d) the allative marker -pie (here reduced to - $p$ ) is added twice, i.e. after the adjectival ending and after PRON itself. According to Zinkevičius (1958: 52), such forms are still attested in some conservative Lithuanian dialects.

(e) The position of PRON is not yet rigidly fixed in Old Lithuanian: alongside the suffixal position, the prefixal one is also attested; specifically, it could be inserted between a prefix and the adjectival stem, as, for example, in the form paioprasta 'of the simple' in (21a), where the preverb pa- is followed by the PRON element -io- and then by the adjectival stem; in Standard Lithuanian, and modern orthography, the same word becomes paprastojo. ${ }^{8}$

(f) Furthermore, in Old Lithuanian (as well as in some conservative modern dialects, see Zinkevičius 1958: 54; Petit 2009: 318-319) there are a few examples of PRON being added to a circumstantial complement in the locative or genitive, rather than to an agreeing adjective, not unlike the Slavic construction in (18e). For example, the form danguieiam in (21f) is to be analysed as danguje LOC.SG of dangus 'heaven' which, as a whole, is transformed into a quality modifier through the addition of PRON; indeed, it translates a very similar Greek construction with the article governing a

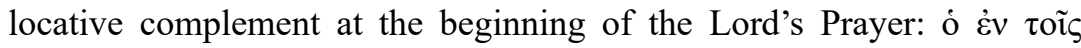
oủpavoĩc.

\footnotetext{
${ }^{8}$ Apparently, PRON still obeyed Wackernagel's law in Old Lithuanian; the reflexive particle $s i$ still exhibits similar behaviour today (cf. Nevis and Joseph 1993).
} 
(g) PRON could be omitted in conjunction, as the example in (21c) illustrates, with two adjectives, tikras 'real, true' and teisus 'right', modifying one and the same noun, with only one PRON being added (namely, in the form teisusis).

(h) On the other hand, PRON could be redundantly repeated, which is another hint of incomplete grammaticalisation; thus, in (21b) the form neiokaltoia 'of the innocent' presents two pronominal elements, -io- and -ia (in modern language and spelling this word becomes nekaltojo).

(i) While Slavic "long" adjectives eventually ousted the "short" ones, in the Baltic domain the "definite" adjectives have not substituted the simple ones and are statistically less frequent. In Modern Lithuanian they are perceived as emphatic, somewhat archaic, and are preferably used in idioms. In some Old Lithuanian texts their use is limited to nominative, genitive and accusative (see Parenti 1996: 37-38).

To summarise, the parallelism of Baltic and Slavic pronominalised adjectives, while commonly assumed as self-evident due to their superficial similarity, is not exempt from criticism. On one hand, Lithuanian tends to be archaic compared to the other IE languages, including those of the Slavic branch, which would explain the late grammaticalisation of PRON. On the other hand, the date of grammaticalisation is so late that it overlaps with a second wave of article cliticisation that spread across Northern Europe at the end of the first millennium A.D. By this I mean, for example, the postnominal article in the Scandinavian languages (see Dahl 2015). Therefore, this Baltic innovation could potentially belong to a different isogloss with respect to the one I am postulating for the other 2nd generation IE languages.

Kuryłowicz (1975) considered crucial the fact that the adjectival wordforms to which the pronoun $j i s, j i$ was cliticised in Baltic were already provided, at least partly, with pronominal endings, unlike the purely nominal declension of the simple adjectives in Slavic. In his opinion Baltic simple adjectives are, therefore, to be compared to the "strong" adjectives in Germanic, rather than the "weak" ones. Table 2 presents a selection from the relevant data in Lithuanian and Gothic; in both languages the adjectival endings match the pronominal ones (in the first two columns), contrasting with the nominal endings (in the last column). 
Table 2. Baltic simple adjectives vs. Germanic "strong" adjectives (based on Kuryłowicz 1975: 427).

\begin{tabular}{llll}
\hline & \multicolumn{3}{c}{ Lithuanian } \\
\cline { 2 - 4 } & $\begin{array}{l}\text { geras } \\
\text { 'good' }\end{array}$ & $\begin{array}{l}\text { jis } \\
\text { 'he' }\end{array}$ & $\begin{array}{l}\text { vyras } \\
\text { 'man' }\end{array}$ \\
\hline dat.sg & ger-am & j-am & vyr-ui \\
loc.sg & ger-ame & j-ame & vyr-e \\
dat.pl & ger-iems & j-iems & vyr-ams \\
\hline
\end{tabular}

\begin{tabular}{llll}
\hline & \multicolumn{3}{c}{ Gothic } \\
\cline { 2 - 4 } & $\begin{array}{l}\text { gops } \\
\text { 'good' }\end{array}$ & 'that, the' & 'dags \\
\hline dat.sg & god-amma & p-amma & dag-a \\
acc.sg & god-ana & p-ana & dag- \\
dat.pl & god-aim & p-aim & dag-am \\
\hline
\end{tabular}

According to Kuryłowicz's hypothesis - today generally abandoned, if remembered at all - in the prehistory of both Germanic and Baltic there must have existed a linking element similar to an article that preceded the adjectives in attributive position; it consequently contaminated them with its own endings, of pronominal origin. As the intermediate stage of this process Kuryłowicz is forced to reconstruct such patterns as Gothic * pamma godamma daga 'to the good day', with both the article and the adjective marked with pronominal endings (whereas in the attested Gothic a "weak" adjective is expected here, e.g. pamma godin daga, see §2.6). Eventually, this reconstructed pronominal linker turned into the plain article in Germanic, and into pronominal clitics of the "definite" adjectives in Baltic.

The main weakness of such a view, besides the unproven reconstructions it is based on, is the fact that the incidence of pronominal endings in adjectival declension keeps increasing in Baltic languages even after the formation of the "definite" pronominalised forms, when the analogy imagined by Kuryłowicz should have already ceased. Indeed, diachronically such forms have been increasing up to the present days. Only a few case-forms of adjectives with pronominal endings are attested in the extant fragments of Old Prussian; see Trautmann (1910: §159-161); Dini (2014: §6.3.2.5). There are up to six such endings in Lithuanian; however, they are limited to the masculine declension: DAT.SG, LOC.SG, DAT.DU, INST.DU, NOM.PL, and DAT.PL. They appear more widespread in the adjectival and even nominal declensions in Modern Latvian. While appealing, the data presented in Table 2 disguises the fact that all the other endings do not follow this model.

On the Germanic side the parallelism does not hold either: the "strong" adjectives are already fully formed at the time of the first attestations, while the article is only an ongoing innovation in Gothic. 
To conclude, I think that the traditional approach on the pronominalised adjectives in Lithuanian is still valid, even if it cannot be considered a common Balto-Slavic innovation, but rather a relatively late offshoot of the same isogloss, perhaps a kind of Sapirean drift, possibly influenced also by the similar innovations in the Scandinavian languages. ${ }^{9}$

\subsection{New suggested examples of "strong" endings}

Germanic and Balto-Slavic data suggest the following generalisation: a typical feature of the 2nd generation IE languages is the development of a new declensional type specialised in marking the quality modifiers of nominal heads. Such modifiers are therefore to be viewed as plain adjectives. With respect to nouns, such adjectival declension is distinguished by longer endings of pronominal origin, which could have originated either from the agglutination of inflected pronouns to nominal forms, or from the direct transfer of pronominal endings. In its later forms, such as Modern German, this system has evolved in a "once-per-phrase principle" (Evans 2019: §3.6): the characteristic "enlargement", i.e. the "strong" ending, appears only once per NP (or DP, if one prefers), and its presence is, in itself, a signal of constituency. In the German examples in (22), the "strong" ending er functions as a phrase-wide constituency marker for the masculine NP; it only appears once per NP, so that it has to switch from one dependent word to another.

\section{(22a) der gute Mann \\ (22b) ein guter Mann \\ (22c) guter Mann}

In the present research I wish to suggest two more examples of a syntactic system of this kind, i.e. such that some phonologically longer endings mark the dependency within a NP: the enlarged oblique adjectival endings in Khotanese and the optional enlarged locative ending in Middle Indian.

\footnotetext{
${ }^{9}$ Ivanov (1979: 62), while excluding Germanic data from the analysis, provides, on the other hand, a strong defence of the idea of Baltic and Slavic parallelism, especially on the ground of certain accentual similarities.
} 


\subsubsection{Khotanese}

In Khotanese, two nominal declension types are attested. One type is characterised by a set of endings that are phonologically longer than the corresponding endings in the other type. The enlargement of the longer endings consists, first of all, of the insertion of the nasal element - $\ddot{a} n$ before the ending proper, e.g.: ABL/INST.SG.F -äñe (vs. nominal $-^{i} e$ ), LOC.SG -äña (vs. nominal $-^{i} a$ ). Another enlarged adjectival ending is GEN/DAT.SG - ye (vs. nominal M $-i$ and $\mathrm{F}-$ ${ }^{i} e$ ). What is important for us here is that the enlarged endings are clearly preferred with adjectives and pronouns, while quite rare, though not unattested, with nouns (see Sims-Williams 1990: 278; Emmerick 2009: 386).

Etymologically, the nasal-enlarged endings are explained by Emmerick (1968: 257ff.) as the result of the contamination from the Old Iranian nominal declension of the nasal stems. Another, more fascinating, reconstruction is suggested by Sims-Williams (1990: 276ff.), who sees in the nasal enlargement the outcome of an agglutinated pronominal stem *ana- (same as Slavic onŭ 'he', Lithuanian anàs 'that', Vedic anắ 'therefore', Hittite anniš 'that'). The GEN/DAT.SG ending is likewise explained by Sims-Williams (1990: 279) as originally pronominal.

Note that there are also "long" endings that do not normally correspond to any short ones: ABL/INST.SG.M -äna and GEN/DAT.PL -ānu. However, in a group of coreferential ABL/INST.SG.M nominals one wordform could lose the nasal element from its case ending, so that the otherwise unattested shortened forms come out, e.g. ABL/INST.SG.M - $\ddot{a}$. An analogy with the aforementioned twofold endings has been claimed in such a case (see Emmerick 1968: 258). This phenomenon, usually referred to as group inflection (see Emmerick 2009: 399), can also be interpreted as a tendency to allow only one occurrence of the nasal enlargement per NP, not unlike the unique occurrence of the "strong" ending per NP allowed in German (though applied less regularly). Sometimes this dropping is explained metri causa, but such an explanation would be more fitting if the dropping of the last syllable always occurred before a caesura, which is not the case. In my opinion, a functional burden can effectively be attributed to this phenomenon: the shortened vs. long endings can encode the relation between a nominal head and its qualifier.

Some examples of Khotanese "long" vs. "short" endings are given in (23); the nasal enlargement is glossed as LRG; the shortened ending is marked $\varnothing$. 
(23a) natäña balysāña rahāśśa

deep-LRG-LOC Buddha's-LOC secret-LOC

'in deep Buddha's secret' (Suv. 4r.2)

(23b) hauva prribhāvana

strength-INST power-LRG-INST

'with powerful strength' $(B c d 51$ v.1)

(23c) purokä- $\varnothing$ Ysarkulna

son-INST Zarkula-LRG-INST

'with the son Zarkula' (manuscript E, add. 12).

Note that the form balysāña in (23a) is a "short" (non-nasalised) locative of the possessive derivative balysāna- from balysa- 'Buddha'. In (23b), which comes from the Late Khotanese, the two wordforms are both nouns, but from the fact that a group inflection is attested we can conclude that one is marked as the head noun, while the other is intended as its nominal epithet. The same goes for (23c), which contains a common noun and a proper name.

To sum up, if the suggested syntactic interpretation is correct, the Khotanese pattern belongs to the category of the "strong" adjectival declension, which is shared by some other 2 nd generation IE languages. The origin of the enlarged endings remains uncertain, but if we accept the pronominal agglutination hypothesis, then it appears to be another case of PRON grammaticalisation. Note that the locus of dependency marking seems unstable, but, on the other hand, the difference between the head vs. dependent status of the two nominals is not always obvious either.

\subsubsection{Middle Indo-Aryan}

Another example of varying case-endings, with one longer and one shorter form, is attested in some Prakrit varieties, including Pāli. Here, as seen above in Khotanese, this alternation is only attested in a few grammatical cases. Namely, the locative case in Prakrit, and the locative and ablative cases in Pâli (which is a prominent isogloss correlating Pāli to the Western MIA area, cf. Oberlies 2001: 1-2). Thus, the old LOC.SG ending $-i /-e$ alternates with the pronominal ending variously spelled as -ammi, -ahmi, -amsi and the like (from Sanskrit -asmin). In Pāli, there is also the ABL.SG termination $-\bar{a}$ alternating with -asma (later -amhā). 
Contrary to Khotanese, no scholar has ever attributed any adjectival function to the Prakrit forms with the "long" endings. However, a convincing explanation of their distribution is lacking, if we except the metri causa reasons quoted by Pischel (1900: $\S 366 a) .{ }^{10}$ Metrical needs do not explain precisely the distribution of the two types of endings. Frequently, they are used alongside each other on coreferential nominals (cf. Woolner 1928: 36 on Māhārāșții), not only in verses, but also in prose. It seems logical to conclude that this alternating marking encodes the dependency relation within the NP, not unlike the adjectival vs. nominal endings in Khotanese, or the "strong" adjectival declension in Germanic.

For example, in Hala's Sattasaï almost every "long" locative ending agrees with a "short" one in the same NP. In (24) some examples are shown ("long" endings are glossed with LRG).

$$
\begin{aligned}
& \text { ditthe sarisammi gune } \\
& \text { viewing similar-LRG-LOC quality-LOC } \\
& \text { 'viewing similar quality' (Sattasaï 44cd) }
\end{aligned}
$$

(24b) putte samāruhattammi

son-LOC climb.up-PART-LRG-LOC

'when the son has climbed up' (Sattasaï 11ab)

(24c) vāsuikaṃkaṇammi osārie snake.bracelet-LRG-LOC remove-PART-LOC 'being the snake-bracelet removed' (Sattasaï 69cd)

The NP in (24c) seems counterintuitive: the nominal that we translate as an adjective has the "short" ending, while the head noun presents the pronominalised ending. But, not unlike what observed in Khotanese, we should not be distracted by our translational equivalents of the Prakrit phrases. The headedness of a NP is questionable. What is translated as 'a bracelet that is removed' could be also understood as 'a removed thing that is a bracelet'. Therefore, for such languages as Khotanese and MIA varieties, where head-marking and dependent-marking strategies alternate unpredictably, I would suggested the term alternant-marking to denote this dependency encoding strategy.

\footnotetext{
${ }^{10}$ Note that this use of the metri causa explanation goes against with what is usually done in Greek: there, metre is used to confirm some apparently aberrant forms as genuine; here, instead, metre is invoked when one needs to dismiss some aberrant forms as poetic artifacts.
} 
Moreover, Edgerton (1936: 66) has collected a series of examples from Buddhist Hybrid Sanskrit (which was heavily influenced by the Prakrit Sprachgefühl of the Buddhist writers), where a nominal modifier with a standard caseending is referred to a nominal head terminating in the simple $-a$, i.e. the bare stem of the word. This sort of group inflection is also attested in Prakrit, see Burrow (1937: §136). Some BHS examples are listed in (25), all from Lalitavistara (in simplified spelling); the "short" ending is shown as $\varnothing$ in the first line.

(25a) ārogya- $\varnothing$ dhig vividhavyādhiparāhatena health-INST fie various.desease.afflicted-INST 'fie upon health, which is afflicted with all sorts of diseases' (191.3)

(25b) jinaratna- $\varnothing$ jambunilaye dharmākarasya udbhavạ̣ Jina.jewel-GEN jambu.home-LOC law.maker-GEN birth-NOM 'in jambu's home Jina-jewel, the maker of the law, is born' (109.4)

The source of the "long" case-endings in Prakrit is in no way correlated to the Vedic "quasiarticle" discussed in §2.1.2. In my opinion, this is a possible case of agglutination of the same short, "ending-like", demonstrative pronouns already mentioned with reference to Germanic (see p. 23). Such pronouns are still attested in MIA, cf. Pāli inflected forms of the pronoun ayam 'it': ABL asma a, GEN assa, LOC asmim; to be compared with the endings of the declension of dev- 'god': ABL dev-asmā, GEN dev-assa, LOC dev-asmi.

One important difference with the situation in Germanic is that MIA varieties did not retain this construction in the later phases. Another difference is found in the limited diffusion of the pronominalised endings within the paradigm (one or two case-forms). This is, however, less problematic than it seems. In the present survey we have already met patterns with a limited diffusion on a number of occasions. Thus, the Avestan "quasi-article" has a partial attestation, regarding the case category. It remains indeterminable whether the cases in which it is not attested were also paradigmatically excluded. Another partial attestation is that of the Old Prussian and Old Lithuanian "definite" adjectives (cf. Probert 2015: 412, fn. 56); only in Modern Lithuanian are such endings attested throughout the whole paradigm. In some other modern Balto-Slavic languages the "definite" endings have been phonologically reduced, so that differences between the nominal endings are almost undetectable in many case-forms.

What makes the MIA locative so special as to be worthy of a particular marking? To start with, it was the case of the absolute construction, which 
made it syntactically more prominent in comparison to the other oblique cases. This could be also the reason why the locative was often among the last cases to survive, after the general collapse of the case endings in MIA. Thus, in the MIA variety studied by Burrow (1937: 56ff.), a general merger, both functional and often also formal, of nominative, accusative, genitive (itself resulting from the coalescence with dative), and instrumental, is observed. We can conclude then that the pronominalised ending was limited to the only oblique case functionally surviving in the MIA case system.

\subsection{Latin}

Latin attests a number of verbless relative constructions with qui, quae, quod (from the PIE stem $*^{w i} i$ ), see the examples in (26).

(26a) qui patres qui conscripti

REL-NOM fathers-NOM REL-NOM registered-NOM

'the fathers, the enlisted ones' (Festus, 338.25)

(26b) divi qui potes pro illo quod gods-NOM REL-NOM powerful-NOM for that-ABL which-ACC

Samothraces theoe dynathoe

Samothracians-NOM $\theta \varepsilon$ oì $\delta v v \alpha \tau o i ́$

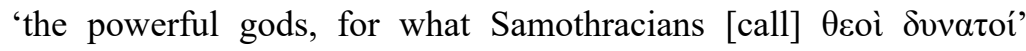
(Varro, L.L., 5.58)

(26c) salvete Athenae quae nutrices Graeciae rejoice Athens-NOM REL-NOM nurse-NOM Greece-GEN 'Hail, Athens, the nurse of Greece' (Plautus, Stichus, 649)

(26d) sed nihil quod crudele utile but nothing-NOM REL-NOM cruel-NOM useful-NOM 'but nothing that is cruel is useful' (Cicero, Off., 3.46)

(26e) quae futura et quae facta eloquar REL-NOM future-NOM and REL-NOM done-NOM I will tell 'I will tell [you] the future and the past' (Plautus, Amph., 1133) 
Benveniste (1966: 220) enthusiastically refers to these Latin examples, especially the first three, as supporting his idea of a PIE article-like construction. However, his use of Latin examples must be critically revised. Latin is known for permitting the elision of the predicate for stylistic purposes (see Lavency 1998: 112-113). The elision of the verb, in the case that it occurs in a relative clause, produces a verbless relative. However, the elision is by no means restricted to relative clauses. Verbless relatives that are found in Latin sources, from Archaic to Classic Latin, are therefore just a by-product of a general rule of syntax, not a grammaticalised pattern.

Only the first two examples are true archaisms. The one in (26a) is a legal formula referring to the members of the Roman Senate. It is not unproblematic: in many editions the two occurrences of qui are interpreted as interrogative, rather than relative pronouns (Benveniste apparently ignores this interpretation). The example in (26b) is a quote from Augurum Libri, an archaic divination text. Note, however, that, according to the general tendency, the second clause also lacks the predicate (supplied in translation), which makes the first verbless clause less specific. Benveniste also includes the example in (26c) in his data, but Plautus is not always reliable as a source of Archaic Latin: he is known for combining together true archaisms, vernacular expressions and even learned calques on Greek.

Thus, the data is very limited and unsystematic. No signs of grammaticalisation are detectable, besides the lack of the verb. Such scarce data can be considered of some use if the verbless relative is considered a remnant of a PIE article-like construction. However, in the present study we assume that this is an innovation. Yet, Latin does not show any diachronic reinforcement of this construction, i.e. it has no reflexes in Romance languages.

For these reasons, I suggest excluding Latin material from the present analysis.

\subsection{Anatolian}

According to the suggestion made by Held (1957) and widely accepted since then, Hittite distinguished two relative patterns: the indeterminate one, with sentence-initial relative pronoun kuiš, and the determinate one, with kuiš in enclitic position. These constructions are normally plain clauses, and only in some occasions verbless relatives are observed. Benveniste (1966: 218) includes them in his corpus of reflexes of the presumed PIE article construction. 
So too does Ivanov (1979: §3.1.4), even if he is mostly interested in clausal relatives, with little reference to verbless ones.

In (27) some such Hittite examples are presented.

armauwanteš kuiēš nu-za ape ya UL haš̌šanzi pregnant-NOM REL-NOM and they-NOM too NEG give birth 'neither the pregnant will give birth' (KUB 17.10 I 15)

(27b) kuit ḩandan apāt īšša

REL-NOM right-NOM that-ACC do

'do what is right' (KUB 13.2 III 28)

(27c) šallayaš kan DINGIR ${ }^{\text {meš }}$-aš kuiš $\quad$ šalliš

great-DAT.PL PTC gods-DAT.PL REL-NOM.SG great-NOM.SG 'the greatest of the great gods' (KUB 31.141 3)

(27d) kuiēš daranteš kuiēš UL daranteš

REL-NOM named-NOM REL-NOM NEG named-NOM

'those named and those unnamed' (KUB 6.45 III 5-6)

(27e) nu-tta-kkan kuit ZAG-na nu apāt uppi CONJ You-DAT PCL REL-NOM right-NOM CONJ that-ACC send 'what is right for you, send it to me' (KBo 2.11 rev. 14)

According to Benveniste, Hittite attests "the same" construction as the one seen in Avestan, Greek etc., the only difference being the source of the pronominal linker: PIE $* k^{w} i$ - instead of $*_{i o-}$ (similarly to Latin). Ivanov (1979) claims that Hittite quality modifiers with a "postclitic" PRON are exact parallels of the pronominalised adjectives in Balto-Slavic. However, this is not the case in all the occurrences. The real rule for kuis positioning could simply be Wackernagel's law, including the cases where it breaks the boundaries of the modifier phrase. Thus, in (27e) PRON is inserted inside the PP serving as a qualifier; in (27c) it interrupts an Adjectival Phrase.

The PRON construction in Hittite is at the very beginning of the grammaticalisation process: verbless relatives are rare and non-systematic, the word order is not fixed, there is no agreement in case between the head noun and the relative pronoun. Moreover, Hittite is known to allow verbless clauses even more than Latin, so all the cautions apply also here. Hittite data could therefore appear as unreliable and dismissible as Latin, but there are, in this case, good justifications for including the Anatolian domain into the isogloss. 
First, the bilingual Akkadian-Hittite "dictionaries" often translate Akkadian adjectives or participles as relative constructions in Hittite. Thus, Hittite dammeškizzi kuiš 'who shows power' translates Akkadian hāailu 'powerful' (KBo I 42 II 31); see Ivanov (1979: 46-48). This attests to the fact that, in the intuition of Hittite speakers, kuiš was already somewhat more grammaticalised than a plain relative pronoun.

But, most importantly, in later Anatolian languages, including Cuneiform and Hieroglyphic Luwian, as well as Lycian, this construction is sporadically attested; see the examples in Hajnal (1997: 56). But it is the recently deciphered Carian that shows a rich evidence of a fully grammaticalised linker, the particle $\hat{k i}$, marking the nominal modifiers which are mostly patronymics and ethnic names. Two funerary inscriptions from Memphis, around the seventh Century B.C., are displayed in (28); the relative element is glossed as REL; the original punctuation symbol "|" is preserved and glossed with a comma; some omitted words are supplied in translation.

(28a) iturowś | kbjomś | k̂̀ en $\quad$ mwdonś $\quad \hat{k} i$ Iturow-GEN , Kbjom-GEN, REL mother-NOM , Mwdon-GEN REL '[Stele of] Iturow, who [is] the mother of Kbjom, of Mwdon [people]' (E.Me 32)

(28b) šýinś | upe |arieś k̂̀i ted Šýin-GEN, stele-NOM, Arie-GEN REL father-NOM

'Stele of Šýin, who [is] the father of Arie' (E.Me 38)

According to a commonly accepted hypothesis (see Adiego 2007: 273; Hajnal 1997), the particle $k \hat{\imath}$ functioned as a relative pronoun if posed in proclitic position (cf. ki en 'who [is] the mother' and ki ted 'who [is] the father'), but was a nominal determiner if in "postclitic" position (cf. mwdons' $\hat{k i}$ 'of Mwdon'); note that the position is inferred from the distribution of the vertical strokes, supposing that they separated prosodic units. Therefore, $k i$ should be considered another example of grammaticalised PRON, functioning as a dependentmarking clitic.

\subsection{Summarising linguistic data}

Table 3 summarises the data surveyed in the preceding sections. The parameters defined in $\S 1.4$ are given the values corresponding to each of the languages 
taken into consideration so far, in its most typical representation (excepting Vedic, since it is not grammaticalised enough, and Latin, since the corresponding data have been rejected). "Position" distinguishes two values: "pre" (for prefixes and proclitics) and "post" (for suffixes and "postclitics"). In the "source" column, the value "ending" stands for pronominal ending of whatever origin.

Table 3. Summing up the parameters.

\begin{tabular}{|c|c|c|c|c|}
\hline & Locus & Autonomy & Position & Source \\
\hline Persian & head & \multirow{2}{*}{ clitic } & post & $*_{\mathrm{SO}}+\mathrm{io}-$ \\
\hline Greek & double & & \multirow{3}{*}{ pre } & $*_{\text {so }}\left(\right.$ also $*_{i o}$ ) \\
\hline Avestan & \multirow{5}{*}{ dependent } & \multirow{2}{*}{ free } & & $*_{i}$ io- \\
\hline Armenian & & & & $* k w o-$ or $* i o-$ \\
\hline Slavic & & \multirow{5}{*}{ bound } & \multirow{7}{*}{ post } & \multirow{2}{*}{$*_{i o-}$} \\
\hline Baltic & & & & \\
\hline Germanic & & & & \multirow{3}{*}{ ending } \\
\hline Khotanese & \multirow{2}{*}{ unstable } & & & \\
\hline Prakrits & & & & \\
\hline Hittite & \multirow{2}{*}{ dependent } & free & & \multirow{2}{*}{$* k^{w i-}$} \\
\hline Carian & & clitic & & \\
\hline
\end{tabular}

\section{A survey of preceding studies}

It is interesting to observe that no scholar has ever described the entirety of the data analysed in the present study as one whole isogloss (thus, Khotanese and MIA varieties have been added to the discussion for the first time here). However, specific connections between single languages have been often proposed and are, in some case, generally accepted by specialists.

Thus, on the one hand, a strong defence of the Irano-Slavic convergent grammaticalisation of the relative pronoun as an adjectival marker is presented by Meillet (1934); cf. the criticism in Parenti (1996: 36), and the approach of Petit (2009: 355), who apparently accepts the Balto-Slavic common development, while rejecting the connection to other IE branches. On the other hand, the parallelism of the Slavic "long" adjective with Germanic "strong" declension has been suggested since Leskien (1876), and is often also shared by mod- 
ern scholars (Dyen 1990); cf. criticism in Kuryłowicz (1975). Meyer (2017) adds Armenian verbless relatives to the discussion.

Benveniste (1966) considers a large number of verbless relative constructions to be connected, including Vedic, Avestan, Balto-Slavic, Greek (limitedly to ö $\varsigma$, ๆ̆, ö), Hittite, and Latin; same data are presented also in Ivanov (1979), with the explicit exclusion of Germanic. Hajnal (1997) adds more Anatolian data, including Carian.

The Iranian "quasi-article" has been sometimes connected to the Greek article $\dot{0}, \dot{\eta}, \tau o$, especially in its archaic pattern. Thus, Schwyzer and Debrunner (1939-1950: II, 26, fn. 1) suggest the parallelism of the Greek postnominal attributive article with the New Persian attributive ezâfe construction. Seiler (1960), discussing Avestan relatives, mentions both Greek constructions; on the other hand, Probert (2015), focusing on Greek relatives, gives reference to the parallel patterns in other IE branches. Interestingly, the parallelism of (New) Persian ezäfe with the (Modern) Greek use of the article is considered obvious in many synchronic studies devoted to the linking function, such as Lehmann (2018) and Franco et al. (2015).

Table 4 sums up these partial results; "+" means that such language is mentioned in connection with the discussed construction, while "-" means that such connection is explicitly criticised or denied. Prakrits and Khotanese are not included since they have not been considered by preceding scholars.

Table 4. The isogloss shape according to other scholars.

\begin{tabular}{l|c|c|c|c|c|c|c|c|c|c|c}
\hline & Ved. & Av. & Pers. & Gr. & Slav. & Balt. & Germ. & Lat. & Hit. & Car. & Arm. \\
\hline Leskien (1876) & & & & & + & + & + & & & & \\
\hline Dyen (1990) & & & & & + & + & + & & & & \\
\hline Bauer (2007) & & & - & & + & + & + & & & & \\
\hline Meillet (1934) & & + & & & + & & & & & & \\
\hline Vaillant (1942) & + & + & + & + & + & + & + & & & & \\
\hline Parenti (1996) & & & & & - & - & & & & & \\
\hline Petit (2009) & - & - & - & - & + & + & - & - & - & & \\
\hline Benveniste (1966) & + & + & + & + & + & + & & + & + & & \\
\hline Ivanov (1979) & + & & & + & + & + & - & + & + & & \\
\hline Kuryłowicz (1979) & & & & & - & - & - & & & & \\
\hline Seiler (1960) & + & + & + & + & + & + & & & & & \\
\hline Hajnal (1997) & + & + & + & + & + & + & + & + & + & + & \\
\hline Meyer (2017) & + & + & + & + & & & & + & + & & + \\
\hline
\end{tabular}


Unifying set-theoretically all the partial pairings proposed so far seems therefore only a logical step in order to present the whole picture of this innovation.

\section{Concluding remarks}

The data reviewed in the preceding sections are consistent with the idea of an innovative isogloss spread among 2 nd generation IE languages. More specifically, two zones can be delineated: the center of the innovation and a periphery, where the innovation is detectable with more difficulty.

The following is a general description of the isogloss, in a vaguely chronological order.

The grammaticalisation of PRON going back to PIE *io- starts in ProtoIndo-Iranian and is brought to the degree of a "quasi-article" in Avestan. Some time later it appears in Old Persian, with a different pronominal stem which results from the concatenation of PIE * so and *io-. Eventually this constructions evolves into the New Persian ezâfe. Noteworthy is the fact that in the Middle Iranian varieties different particles sometimes compete for the function of PRON.

A similar competing situation is attested also in Homeric Greek, which presents two verbless constructions, one with a pronominal element from PIE $*_{i o}$ - and the other from $*_{s o}$. Eventually, the latter ousted the former, giving rise to the Classical Greek article (cf. Probert 2015: 414); the PRON functions have been, so to say, "passed" from one pronoun to the other. The linear order HEAD PRON MODIFIER, parallel to Old Persian, soon became a minority, while the double marking "polydefinite" construction arose.

A verbless relative construction similar to the Middle Iranian one is also attested in Classical Armenian. Similarly, Slavic "long" adjectives correspond to a different configuration of the same basic elements.

In the Anatolian linguistic domain we observe a very early stage of grammaticalisation of PRON in sporadic occurrences in Hittite. The main difference is found in the source of the linking element, which is *kwi-. The diachronic enforcement of this innovation is confirmed by Carian, where a late outcome of the same pronominal stem seems completely grammaticalised.

So far we have considered the centre of the innovation. In the periphery we find a series of languages whose constructions are less similar to those attested in the central zone. All such languages present a special adjectival declension with longer endings, compared to the shorter nominal ones. If we ac- 
cept the agglutination hypothesis concerning the origin of such "strong" declensional types, then they appear as part of the same grammaticalisation process seen in the centre of the isogloss. The evidence at our disposal is not sufficient to confirm or refute such a claim, but a typological affinity of the "strong" declension of the adjectives with the morphological devices found in the central languages cannot be denied. Among the peripheral languages should be mentioned Germanic, but also some Eastern varieties, such as Khotanese and Middle Indo-Aryan. Chronologically the last languages to follow this drift are the Baltic ones.

Concerning the origin of the isogloss, the genetic hypothesis, defended by Benveniste (1966) and Ivanov (1979), seems untenable for the reason that a unique PIE source for PRON cannot be reconstructed. As a matter of fact, Benveniste calls an archaism what is only a set of typologically parallel innovations in the daughter languages, not a genetic correspondence. Indeed, in each language where it is attested we observe a diachronic increase in grammaticalisation, which counters the idea of the archaism.

The initial motivation of the innovation must have been purely syntactic: the reinforcement of the constituency marking within the NP. The semantics of definiteness (or the like) is involved in this process only as a means, not the main goal. Languages often use semantic or pragmatic categories (such as gender, definiteness, etc.) just for creating an agreement pattern that serves the needs of constituency. In my opinion, an exaggerated attention to the semantic functions of articles or adjectival declension prevented many scholars from seeing the grammaticalisation of PRON as one whole innovation. Bauer (2007: 109) fails to recognise the New Persian ezäfe as the natural development of the Old Persian "quasi-article" only because the latter cannot be explained in the same terms of determinacy marking as the former. Likewise, the connection of Germanic "strong" adjectives to the Slavic pronominalised adjectives has often been questioned because of the reversed value of determinacy they express. Ignoring all such facts, in my opinion, allows us to make broader and more fruitful generalisations.

One more important thing to remark is that this innovation must be recognised as a typical feature of the 2 nd generation IE languages.

\section{Acknowledgments}

I wish to thank my colleagues who kindly revised preliminary drafts of this paper providing invaluable feedback either on single linguistic examples, or 
on the paper in general, for instance: Claudia A. Ciancaglini, Alessandro del Tomba, Alessandro Papini, Irina Pekunova, Valerio Pisaniello, and Artūras Ratkus. My gratitude goes also to the anonymous PSiCL reviewers whose remarks helped me to correct regrettable mistakes and to refine the argumentation. As usual, the responsibility for any errors or deficiencies rests with me.

\section{REFERENCES}

Adiego, I.J. 2007. The Carian language. Leiden \& Boston: Brill.

Alfieri, L. 2016. "The definition of the root between history and typology". Archivio Glottologico Italiano 101(2). 129-169.

Bakker, S.J. 2009. The noun phrase in Ancient Greek. A functional analysis of the order and articulation of NP Constituents in Herodotus. Leiden \& Boston: Brill.

Bammesberger, A. 1990. Die Morphologie des urgermanischen Nomens. Heidelberg: Winter.

Bauer, B.L.M. 1995. The emergence and development of SVO patterning in Latin and French. Diachronic and psycholinguistic perspectives. Oxford \& New York: Oxford University Press.

Bauer, B.L.M. 2007. "The definite article in Indo-European: Emergence of a new grammatical category?" In: Stark, E., E. Leiss and W. Abraham (eds.), Nominal determination. Typology, context constraints, and historical emergence. Amsterdam \& Philadelphia: Benjamins.

Belardi, W. 1990. "Genealogia, tipologia, ricostruzione e leggi fonetiche". In: Linguistica generale, filologia e critica dell'espressione. Roma: Bonacci. 155-216.

Belardi, W. 1993. "Sulla tipologia della struttura formale della parola nelle lingue indoeuropee". Rendiconti dell'Accademia Nazionale dei Lincei. Classe delle scienze morali 9(4.4). 535-570.

Benveniste, É. 1966. "La phrase relative, problème de syntaxe générale". In: Problèmes de linguistique générale. Paris: Gallimard. 208-222.

Burrow, T. 1937. The language of the Kharost thi documents from Chinese Turkestan. Cambridge: Cambridge University Press.

Caland, W. 1891. Zur Syntax der Pronomina im Avesta. Amsterdam: Müller.

Chantraine, P. 1942-1953. Grammaire homérique. Paris: C. Klincksieck.

Dahl, Ö. 2015. Grammaticalization in the North. Noun phrase morphosyntax in Scandinavian vernaculars. Berlin: Language Science Press.

Dini, P.U. 2014. Foundations of Baltic languages. Vilnius: Vilnius University.

Dunkel, G.E. 2014. Lexikon der indogermanischen Partikeln und Pronominalstämme. Vol. 2. Heidelberg: Winter.

Durkin-Meisterernst, D. 2014. Grammatik des Westmitteliranischen (Parthisch und Mittelpersisch). Wien: Verlag der Österreichischen Akademie der Wissenschaften. 
Dyen, I. 1990. "The homomeric argument for a Slavo-Germanic subgroup of IndoEuropean”. In: Baldi, P. (ed.), Linguistic change and reconstruction methodology. Berlin: De Gruyter Mouton. 385-390.

Edgerton, F. 1936. "Nouns of the a-declension in Buddhist Hybrid Sanskrit". Harvard Journal of Asiatic Studies 1(1). 65-83.

Emmerick, R.E. 1968. Saka grammatical studies. London: Oxford University Press.

Emmerick, R.E. 2009. "Khotanese and Tumshuqese". In: Windfuhr, G. (ed.), The Iranian languages. (Chap. 7.) London \& New York: Routledge. 377-415.

Evans, E. 2019. The origin, functions, and histories of Germanic adjective endings". (PhD thesis, Indiana University, Department of Germanic Studies.)

Franco, L., M.R. Manzini and L.M. Savoia. 2015. "Linkers and agreement". The Linguistic Review 32(2). 277-332.

Gildersleeve, B.L. 1900-1911. Syntax of Classical Greek. From Homer to Demosthenes. New York, Cincinnati \& Chicago: American Book Company.

Haider, H. and R. Zwanziger. 1984. "Relatively attributive: The 'ezāfe'-construction from Old Iranian to Modern Persian”. In: Fisiak, J. (ed.), Historical syntax. Berlin \& New York: Mouton de Gruyter. 137-172.

Hajnal, I. 1997. "Definite nominale Determination im Indogermanischen". IndogermanischeForschungen 102. 38-73.

Haspelmath, M. 2001. "The European linguistic area. Standard Average European". In: Language Typology and Language Universals. Berlin: De Gruyter. 14921510 .

Held, W.H. 1957. "The Hittite relative sentence”. Language 33(4.2). 7-52.

Humbert, J. 1960. Syntaxe grecque. (3rd ed.) Paris: Klincksieck.

Ivanov, V.V. 1979. "Sravnitel'no-istoričeskij analiz kategorii opredelennosti-neopredelennosti v slavjanskix, baltijskix i drevnebalkanskix jazykax v svete indoevropeistiki i nostratiki”. In: Nikolaeva, T.M. (ed.), Kategorija opredelennosti-neopredelennosti v slavjanskix i balkanskix jazykax. Moskva: Nauka. 11-63.

Keidan, A. 2013. "Branch-crossing Indo-European isoglosses: A call for interest". Indoevropejskoe âzykoznanie i klassičeskaâ filologiâ 17. 406-417.

Kuryłowicz, J. 1975. "Die Flexionen des Adjektivs im Baltischen und im Slavischen". In: Coseriu, E. (ed.), Esquisses Linguistiques II. München: Fink. 426-438.

Lavency, M. 1998. Grammaire fondamentale du latin. V.2. La proposition relative. Louvain \& Paris: Peeters.

Lehmann, C. 2018. "Adjective and attribution. Category and operation”. In: Baumann, C., V. Dabóczi and S. Hartlmaier (eds.), Adjektive. Grammatik, Pragmatik, Erwerb. Berlin: De Gruyter. 13-76.

Lejeune, M. 1973. "La grande inscription celtibère de Botorrita (Saragosse)". Comptes rendus des séances de l'Académie des Inscriptions et Belles-Lettres 117(4). 622648.

Leskien, A. 1876. Die Declination im Slavisch-Litauischen und Germanischen. Leipzig: Hirzel.

Luján, E.R. 2009. "On the grammaticalization of $* k^{w} i-/ k^{w} O-$ relative clauses in ProtoIndo-European”. In: Bubeník, V., J. Hewson and S. Rose (eds.), Grammatical change in Indo-European languages. Amsterdam \& Philadelphia: Benjamins. 
McFadden, T. 2004. "On the pronominal inflection of the Germanic strong adjective". University of Pennsylvania Working Papers in Linguistics 10(1). 123-136.

Meillet, A. 1906-1908. "La phrase nominale en indo-européen". Mémoires de la Société de Linguistique de Paris 14. 1-26.

Meillet, A. 1915. Grammaire du vieux Perse. Paris: Guilmoto.

Meillet, A. 1934. Le slave commun. (Ed. by A. Vaillant. 2nd ed.) Paris: Champion.

Meyer, R. 2017. Iranian-Armenian language contact in and before the 5th century CE. An investigation into pattern replication and societal multilingualism. $(\mathrm{PhD}$ thesis. Oxford: University of Oxford.)

Nevis, J.A. and B.D. Joseph. 1993. "Wackemagel affixes: Evidence from BaltoSlavic". In: Booij, C. and J. v. Marie (eds.), Yearbook of morphology 1992. Kluwer Academic Publishers. 93-111.

Nichols, J. 1986. "Head-marking and dependent-marking grammar”. Language 62(1). $56-119$.

Nyberg, H.S. 1964-1974. A manual of Pahlavi. Wiesbaden: Harrassowitz.

Oberlies, T. 2001. Pāli. A grammar of the language of the Theravāda Tipitaka. Berlin $\&$ New York: Walter de Gruyter.

Orr, R. 1983. "The twofold adjective declension in Germanic and Slavic (with some reference to Baltic): A contrastive/comparative analysis". Zeitschrift für vergleichende Sprachforschung 96(1). 104-118.

Parenti, A. 1996. "L'aggettivo determinato lituano e l'evoluzione delle marche di definitezza”. In: Benacchio, R., F. Fici and L. Gebert (eds.), Determinatezza e indeterminatezza nelle lingue slave. Padova: Unipress. 27-42.

Petit, D. 2009. "La préhistoire des adjectifs déterminés du baltique et du slave". Bulletin de la Société de Linguistique de Paris 104. 311-360.

Pisani, V. 1950. "Studi sulla fonetica dell'armeno. I. Palatalizzazioni ed esiti di s + gutturale; esiti delle semivocali". Ricerche Linguistiche 1. 165-193.

Pischel, R. 1900. Grammatik der Prakrit-Sprachen. Strassburg: Trübner.

Polivanova, A. K. 2013. Staroslavjanskij jazyk. Grammatika. Slovari. Moskva: Institut Slavjanovedenija.

Probert, P. 2015. Early Greek relative clauses. Oxford: Oxford University Press.

Prokosch, E. 1939. A comparative Germanic grammar. Philadelphia: Linguistic society of America.

Ratkus, A. 2015. "Gothic possessives, adjectives, and other modifiers in -ata". Journal of Germanic Linguistics 27(3). 238-307.

Ratkus, A. 2018. "Weak adjectives need not be definite. The evidence of variation in Gothic". Indogermanische Forschungen 123(1). 27-64.

Rosinas, A. 1975. “Ar baltų $*_{i-}, *_{i o-}$ resp. $*_{\bar{l}},{ }^{*} i \bar{a}$ - kamienai buvo reliatyviniai?” Baltistica 11(2). 165-170.

Schmitt, R. 2014. Wörterbuch der altpersischen Königsinschriften. Wiesbaden: Reichert.

Schwyzer, E. and A. Debrunner. 1939-1950. Griechische Grammatik. München: C. H. Beck.

Seiler, H. 1960. Relativsatz, Attribut und Apposition. Wiesbaden: Harrassowitz. 
Sievers, E. 1876. "Kleine Beitrage zur deutschen Grammatik III. Die starke Adjectivdeclination". Beitrage zur Geschichte der deutschen Sprache und Literatur 2. 98-124.

Sims-Williams, N. 1990. "Chotano-Sogdica II. Aspects of the development of nominal morphology in Khotanese and Sogdian”. In: Gnoli, G. and A. Panaino (eds.), Proceedings of the first European conference of Iranian studies, held in Turin, September 7th-11th, 1987. (Vol. 1.) Rome: IsMEO. 276-296.

Strunk, K. 1967. "Wortstruktur und Pronomen im Altpersischen". Zeitschrift für vergleichende Sprachforschung auf dem Gebiete der Indogermanischen Sprachen 81(3-4). 265-275.

Trautmann, R. 1910. Die altpreussischen Sprachdenkmäler. Göttingen: Vandenhoeck und Ruprecht.

Vaillant, A. 1942. "L'article en vieux slave". Revue des Études Slaves 20. 5-12.

Večerka, R., R.M. Cejtlin and Ė. Blagova. 1994. Staroslavjanskij slovar' po rukopisjam $X-X I$ vekov. Moskva: Russkij jazyk.

West, M.L. 2011. Old Avestan syntax and stylistics. Berlin: De Gruyter.

Wissemann, H. 1957. “Zur nominalen Determination”. Indogermanische Forschungen 63. 61-78.

Woolner, A.C. 1928. Introduction to Prakrit. (2nd ed.) Lahore: Punjab University.

Zinkevičius, Z. 1958. "Nekotorye voprosy obrazovanija mestoimennyx prilagatel'nyx v litovskom jazyke”. Voprosy slavjanskogo jazykoznanija 3. 50-100.

\author{
Address correspondence to: \\ Artemij Keidan \\ Sapienza University of Rome \\ Institute of the Oriental Studies \\ Circonvallazione Tiburtina 4 \\ Roma, RM 00185 \\ Italy \\ artemij.keidan@uniroma1.it
}

